\title{
Diversidade de plantas trepadeiras do Parque Nacional do Catimbau, Pernambuco, Brasil
}

Diversity of climbing plants in Parque Nacional do Catimbau, Pernambuco, Brazil

\author{
Geadelande Carolino Delgado-Junior ${ }^{1,3}$ \& Marccus Alves ${ }^{2}$
}

\begin{abstract}
Resumo
O estudo foi realizado no Parque Nacional do Catimbau, Pernambuco, Brasil. Foram encontradas 101 espécies de plantas trepadeiras, distribuídas em 54 gêneros e 18 famílias. As famílias com maior diversidade foram Convolvulaceae (23) Apocynaceae (13), Fabaceae (12) e Malpighiaceae (11). As trepadeiras lenhosas e as trepadeiras herbáceas tiveram um valor equivalente a $51 \%$ e $49 \%$, respectivamente. O mecanismo de ascensão mais frequente foi o volúvel, ocorrendo em $68 \%$ das espécies. São apresentadas novas ocorrências na Caatinga e para o estado de Pernambuco, uma chave de identificação, comentários das espécies e ilustrações de alguns caracteres diagnósticos.
\end{abstract}

Palavras-chave: Caatinga, florística, flora, lianas, taxonomia.

\begin{abstract}
This study was undertaken in "Parque Nacional do Catimbau", located in Pernambuco, Brazilian northeastern semiarid, where 101 species of climbing plants were recorded. The species belong to 54 genera and 18 families. The most diverse families were Convolvulaceae (23), Apocynaceae (13), Fabaceae (12) and Malpighiaceae (11). The wood and herbaceous climbing plants have an equivalent values, $51 \%$ and $49 \%$ respectively. As regards the attachment mechanisms, twining was the most frequent, occurring in $70 \%$ of the species. New occurrences of species in Pernambuco and in the Caatinga were recorded. Identification key, descriptions and comments on the species and illustrations of some diagnostic characters are presented.
\end{abstract}

Key words: Caatinga, floristic, flora, lianas, taxonomy.

\section{Introdução}

As plantas trepadeiras são todas aquelas que possuem as raízes fixas ao solo e são incapazes de se manterem erguidas sem um apoio ou suporte externo (Acevedo-Rodríguez 2003). Elas ocorrem na maioria dos ecossistemas terrestres, sendo mais comuns e representativas em florestas tropicais (Schnitzer \& Bongers 2002).

Do ponto de vista florístico e ecológico, as plantas trepadeiras são componentes importantes, contribuindo de maneira significativa na riqueza e diversidade taxonômica, além de participarem de forma expressiva na dinâmica das comunidades, atuando ativamente nos processos de regeneração e sucessão das bordas e clareiras (Putz 1984).
Na Caatinga, as plantas trepadeiras ainda são pouco exploradas, embora nos levantamentos florísticos generalistas correspondam a um índice de até 23\% em relação aos outros hábitos (Araújo 2014). Nos últimos anos, a composição florística da Caatinga vem sendo intensamente estudada e já são reconhecidas 4.657 espécies, destas, 913 são endêmicas (BGF 2015). Este Domínio corresponde a uma das maiores áreas de Florestas Secas Tropicais da América do Sul, com 85.000 $\mathrm{km}^{2}$ e ocupa todos os estados do Nordeste do Brasil (Queiroz 2006; Fiaschi \& Pirani 2009).

No Brasil, os inventários florísticos e/ou trabalhos taxonômicos direcionados às trepadeiras estão concentrados nas regiões Sudeste (Vargas \&

\footnotetext{
${ }^{1}$ Universidade Federal Rural de Pernambuco, Prog. Pós-graduação em Botânica, R. Dom Manoel de Medeiros s/n, Dois Irmãos, 52171-900, Recife, PE, Brasil.

${ }^{2}$ Universidade Federal de Pernambuco, Depto. Botânica, Av. Prof. Moraes Rêgo s/n, 51930-670, Recife, PE, Brasil.

${ }^{3}$ Autor para correspondência: geadelande@gmail.com
} 
Araújo 2014; Vargas et al. 2013; Villagra 2012; Villagra \& Romaniuc-Neto 2010; Udulutsch et al. 2010; Barros et al. 2009; Tibiriçá et al. 2006; Rezende \& Ranga 2005; Sampaio 2004; Udulutsch et al. 2004; Hora 2004) e Sul (Carneiro \& Vieira 2012; Durigon \& Waetcher 2011). No Nordeste brasileiro, os trabalhos são incipientes, e os primeiros foram realizados na Mata Atlântica (Oliveira et al. 2012; García-González 2011; Araújo \& Alves 2010). Em uma abordagem específica para a Caatinga, somente dois trabalhos foram publicados: Cruz et al. (2010) listaram as espécies de trepadeiras da Caatinga em Pernambuco e, Araújo (2014) fez um levantamento das espécies para todo o bioma. Contudo, ambas as listagens foram baseadas apenas em dados de herbários.

Considerando-se o exposto, o trabalho objetivou registrar, caracterizar e fornecer uma chave de identificação para as plantas trepadeiras ocorrentes em uma Unidade de Conservação na Caatinga.

\section{Material e Métodos}

Área de estudo

O Parque Nacional (PARNA) do Catimbau

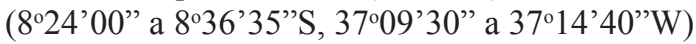
localizado no estado de Pernambuco, Nordeste do Brasil (Fig. 1), possui uma extensão de 62.554 ha (DOU 2002). Segundo a classificação Köppen, o clima é do tipo BSh W com temperatura anual média de $23,7^{\circ} \mathrm{C}$ e precipitação anual média de $700 \mathrm{~mm}$. A estação de seca dura entre 6 a 8 meses (agosto-fevereiro), sendo novembro o mês mais seco e estação chuvosa se concentra nos meses de março a julho, sendo maio o mês com maior índice pluviométrico (SADMET/INMET 2013).

O Parque Nacional do Catimbau é formado por elevações montanhosas de topo suave em forma de mesetas, com altitudes variando de 600 a $1000 \mathrm{~m}$, encostas abruptas e vales abertos e está inserido na Bacia Sedimentar do Jatobá (Rodal et al. 1998; CPRM 2001). Apresenta ao menos quatro fitofisionomias vegetais: campos rupestres, caatinga arbustiva, vegetação arbórea perenifólia e a vegetação arbustiva perenifólia (Rodal et al. 1998). De maneira a viabilizar o reconhecimento das fisionomias observadas na área de estudo, empregou-se as seguintes categorias: caatinga arbustiva de solo arenoso (Caatinga sedimentar), caatinga arbustiva de solo pedregoso (Caatinga de cristalino), afloramentos rochosos e áreas antropizadas.

\section{Coletas de dados}

A coleta dos dados foi efetivada a partir de expedições ao campo e visitas aos herbários. Foram realizadas doze expedições ao campo, de abril de 2012 a setembro de 2013, e uma revisita em 2015, abrangendo os períodos seco e chuvoso. Foram visitados diversos locais do PARNA Catimbau,

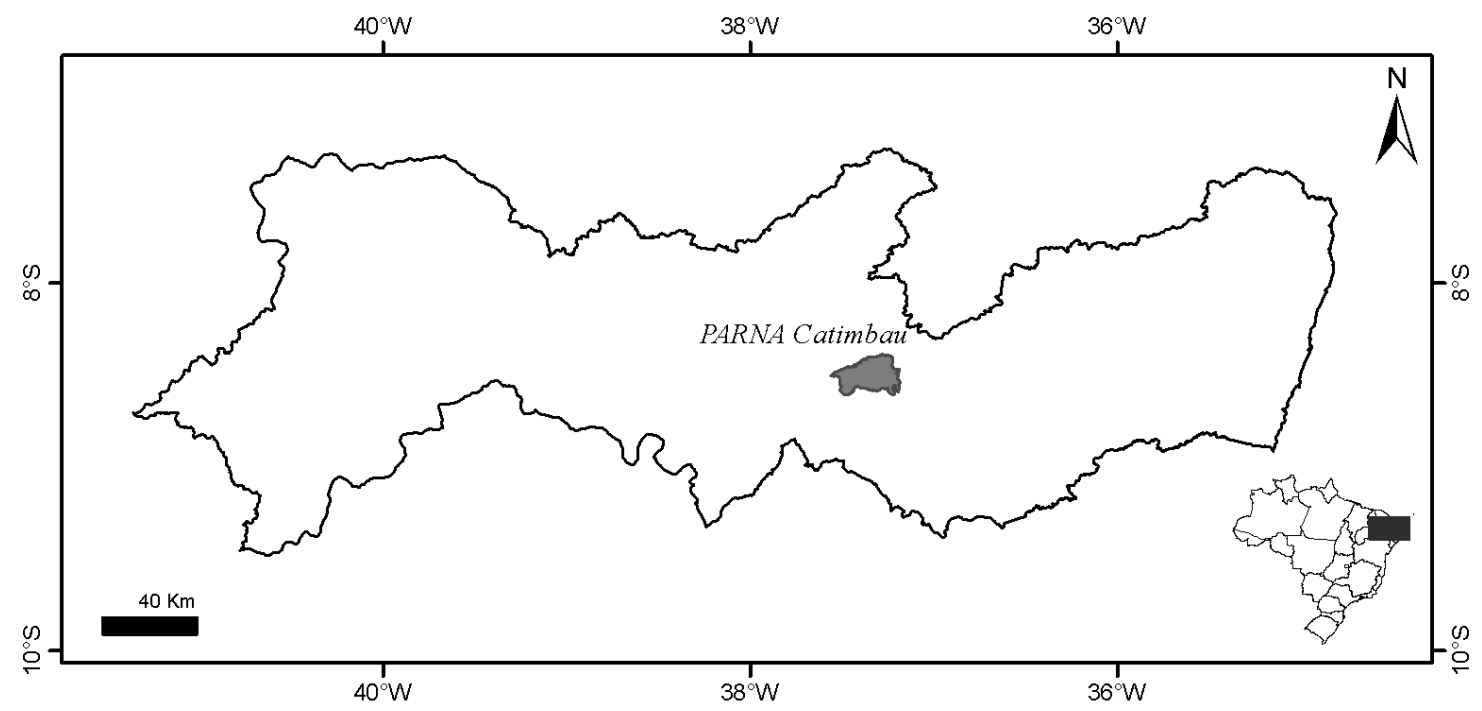

Figura 1 - Localização do PARNA Catimbau, Pernambuco, Brasil.

Figure 1 - Location of PARNA Catimbau, Pernambuco, Brazil. 
visando contemplar a maior abrangência possível da área de estudo.

As amostras botânicas coletadas foram georreferenciadas e submetidas às técnicas usuais em taxonomia vegetal (Mori et al. 1985) e depositadas no Herbário UFP. As duplicatas foram envidadas a herbários do Brasil e do exterior (HST, HUEFS, RB, NY e FR). Foram consultados os acervos dos herbários ASE, HST, HUEFS, HUESB, HVASF, IPA, JPB, PEUFR e UFP (acrônimos de acordo com Thiers, continuamente atualizado), os quais apresentam coleção representativa da flora do PARNA Catimbau e ou da Caatinga.

\section{Tratamento taxonômico}

e análise dos dados

A identidade dos táxons foi estabelecida com base em bibliografia especializada para cada família e gênero, em amostras previamente identificadas por especialistas e análise de materiais-tipo. Os binômios específicos estão de acordo com BFG (2015) e o sistema de classificação adotado foi o APGIV (2016). A terminologia morfológica adotada segue Harris $\&$ Harris (2000) e Stearn (2004).

Os comentários taxonômicos são baseados principalmente em caracteres vegetativos, visando a rápida identificação das espécies que ocorrem no PARNA Catimbau. Além disso, para cada espécie registrada na área de estudo é indicada a ocorrência nos limites do parque.

Para expressar a ocorrência das espécies no PARNA Catimbau foi realizada uma adaptação de Durigon et al. (2009). Foi considerada espécie de ocorrência rara quando encontrado de um a três indivíduos e populações em até duas localidades, ocasional (de 4 a 10 indivíduos e/ou populações em duas a cinco localidades) e abundante (mais de 10 indivíduos e/ou populações distribuídas em mais de cinco áreas).

As espécies foram agrupadas em categorias que refletem o grau de lignificação, segundo Gentry (1991, com adaptações) em: herbáceas (com caule não lignificado ou levemente lignificado e até 2 $\mathrm{cm}$ de diâmetro) e lenhosas (com caule fortemente lignificado e de diâmetro superior a $2 \mathrm{~cm}$ ).

Para classificar o mecanismo de ascensão, adotaram-se duas categorias (Acevedo-Rodríguez 2003): volúveis, as plantas que utilizam o caule para se enroscar em um suporte, e gavinhas. Quanto as fenofases de floração e frutificação, as espécies foram classificadas de acordo com as duas estações marcantes na Caatinga: seca e chuvosa.

\section{Resultados e Discussão}

No Parque Nacional do Catimbau foram registrados 101 táxons incluídos em 18 famílias e 54 gêneros. Esse valor corresponde a $21 \%$ do total de plantas trepadeiras encontradas na Caatinga (Araújo 2014). As trepadeiras lenhosas corresponderam a $51 \%$ e às herbáceas $49 \%$ (Tab. 1 ), o que corrobora a ideia de Gentry (1991) onde ele relata que o número de trepadeiras herbáceas é semelhante às trepadeiras lenhosas nas florestas tropicas.

As famílias mais diversas foram Convolvulaceae (23 spp.), Apocynaceae (13), Fabaceae (12), Malpighiaceae (11) e Bignoniaceae (8). Essas mesmas famílias correspondem também as cinco famílias mais representativas na listagem realizada por Araújo (2014) para as trepadeiras da Caatinga. Em relação aos trabalhos realizados na Mata Atlântica do Sudeste, Bignoniaceae e Fabaceae foram as famílias mais diversas, seguidas de Sapindaceae, Malpighiaceae ou Asteraceae, não necessariamente nesta ordem (Vargas \& Araújo 2014; Villagra \& Romaniuc-Neto 2010; Udulutsch et al. 2010; Barros et al. 2009; Tibiriçá et al. 2006; Udulutsch et al. 2004). Em uma área de Mata Atlântica de Pernambuco (Araújo \& Alves 2010), Fabaceae e Convolvulaceae foram as mais representativas. No Cerrado, Apocynaceae foi a mais diversa. As demais famílias do PARNA Catimbau apresentaram de uma a quatro espécies cada.

Os gêneros com maior número de espécies foram Ipomoea L. (12 spp) e Jacquemontia Choisy (6), ambos pertencentes à Convolvulaceae, Ditassa R.Br. (Apocynaceae), Dioscorea L. (Dioscoreaceae), Centrosema (DC.) Benth. (Fabaceae), Passiflora L. (Passifloraceae) e Serjania Mill. (Sapindaceae) foram representados por quatro espécies cada um.

Das 101 espécies catalogadas, 17 não foram recoletas, apesar das diversas excursões na área de estudo, conforme documentado nas etiquetas das amostras depositadas nos herbários consultados: (Blepharodon manicatum (Decne) Fontella - (Apocynaceae); Cayaponia martiana Cogn., Cayaponia tayuya (Vell.), Cogn., Cucumis anguria L. - (Cucurbitaceae); Merremia cissoides (Lam.) Hallier f., (Convolvulaceae); Centrosema pubescens Benth. - (Fabaceae); Serjania pernambucensis Radlk. - (Sapindaceae). As espécies Ditassa oxyphylla Turcz. - (Apocynaceae); Ipomoea hederifolia L., I. setosa Ker Gawl., Jacquemontia pentanthos (Jacq) G.Don - (Convolvulaceae); Heteropterys caducibracteata W.R. Anderson, H. trichanthera 
Tabela 1 - Espécies de trepadeiras encontradas no PARNA Catimbau, Pernambuco, Brasil. Localidade dentro do parque: C.S. (caatinga sedimentar); C.C. (caatinga cristalina); A.R. (afloramento rochoso); A.A. (área antropizada). Quanto a ocorrência: A (abundante); O (ocasional); R (rara). Mecanismo de ascensão: V (volúvel); G (gavinhas). Hábito: H (herbácea); L (lenhosa).

Table 1 - Climbing plants in PARNA Catimbau, Pernambuco, Brazil. Places in the park: C.S. (caatinga sedimentary); C.C. (caatinga crystalline); A.R. (Rocky outcrop); A.A. (Anthropized area). Occurrence: A (abundant); O (occasional); R (rare). Climbing strategy: V (twining); G (tendril). Habit: H (herbaceous); L (woody).

\begin{tabular}{|c|c|c|c|c|c|c|c|c|c|}
\hline \multirow{2}{*}{ Família/Espécie } & \multicolumn{4}{|c|}{ Localidade } & \multicolumn{3}{|c|}{ Ocorrência } & \multirow{2}{*}{ Asc. } & \multirow{2}{*}{ Hab. } \\
\hline & C.S & C.C & A.R & A.A & $\mathbf{A}$ & $\mathbf{O}$ & $\mathbf{R}$ & & \\
\hline \multicolumn{10}{|l|}{ Asteraceae } \\
\hline Mikania micrantha & $\mathrm{x}$ & & & $\mathrm{x}$ & & & $\mathrm{x}$ & $\mathrm{V}$ & $\mathrm{H}$ \\
\hline \multicolumn{10}{|l|}{ Apocynaceae } \\
\hline Blepharodon manicatum & & & $\mathrm{x}$ & & & & $\mathrm{x}$ & $\mathrm{V}$ & $\mathrm{H}$ \\
\hline Blepharodon pictum & & & & $\mathrm{x}$ & & & $\mathrm{x}$ & $\mathrm{V}$ & $\mathrm{H}$ \\
\hline Ditassa capillaris & $\mathrm{x}$ & & $\mathrm{x}$ & $\mathrm{x}$ & $\mathrm{x}$ & & & $\mathrm{V}$ & $\mathrm{H}$ \\
\hline Ditassa hastata & $\mathrm{x}$ & & $\mathrm{x}$ & $\mathrm{x}$ & & $\mathrm{x}$ & & $\mathrm{V}$ & $\mathrm{H}$ \\
\hline Ditassa oxyphylla & & & & $\mathrm{x}$ & & & $\mathrm{x}$ & $\mathrm{V}$ & $\mathrm{H}$ \\
\hline Ditassa rotundifolia & $\mathrm{x}$ & & $\mathrm{x}$ & & & $\mathrm{x}$ & & $\mathrm{V}$ & $\mathrm{H}$ \\
\hline Mandevilla catimbauensis & $\mathrm{x}$ & & & & & $\mathrm{x}$ & & $\mathrm{V}$ & $\mathrm{H}$ \\
\hline Mandevilla scabra & $\mathrm{x}$ & & $\mathrm{x}$ & $\mathrm{x}$ & & $\mathrm{x}$ & & $\mathrm{V}$ & $\mathrm{H}$ \\
\hline Marsdenia hilariana & $\mathrm{x}$ & & & & & & $\mathrm{x}$ & $\mathrm{V}$ & $\mathrm{L}$ \\
\hline Matelea maritima & & & $\mathrm{x}$ & $\mathrm{x}$ & & $\mathrm{x}$ & & $\mathrm{V}$ & $\mathrm{L}$ \\
\hline Schubertia multiflora & & & & $\mathrm{x}$ & & & $\mathrm{x}$ & $\mathrm{V}$ & $\mathrm{L}$ \\
\hline Skytanthus hancorniifolius & $\mathrm{x}$ & & & & & $\mathrm{x}$ & & $\mathrm{V}$ & $\mathrm{L}$ \\
\hline Temnadenia violacea & $\mathrm{x}$ & & $\mathrm{x}$ & $\mathrm{x}$ & & $\mathrm{x}$ & & $\mathrm{V}$ & $\mathrm{L}$ \\
\hline \multicolumn{10}{|l|}{ Bignoniaceae } \\
\hline Anemopaegma laeve & $\mathrm{x}$ & $\mathrm{x}$ & $\mathrm{x}$ & $\mathrm{x}$ & $\mathrm{x}$ & & & $\mathrm{G}$ & $\mathrm{L}$ \\
\hline Bignonia ramentacea & $\mathrm{x}$ & $\mathrm{x}$ & & & & $\mathrm{x}$ & & G & $\mathrm{L}$ \\
\hline Cuspidaria aff. lateriflora & $\mathrm{x}$ & & & $\mathrm{x}$ & & $\mathrm{x}$ & & G & $\mathrm{L}$ \\
\hline Fridericia dichotoma & $\mathrm{x}$ & $\mathrm{x}$ & & $\mathrm{x}$ & $\mathrm{x}$ & & & G & $\mathrm{L}$ \\
\hline Fridericia limae & $\mathrm{x}$ & $\mathrm{x}$ & & & & $\mathrm{x}$ & & $\mathrm{G}$ & $\mathrm{L}$ \\
\hline Fridericia parviflora & $\mathrm{x}$ & $\mathrm{x}$ & & & & $\mathrm{x}$ & & G & $\mathrm{L}$ \\
\hline Mansoa paganuccii & $\mathrm{x}$ & & $\mathrm{x}$ & $\mathrm{x}$ & & $\mathrm{x}$ & & G & $\mathrm{L}$ \\
\hline Pyrostegia venusta & & $\mathrm{x}$ & & $\mathrm{x}$ & & & $\mathrm{x}$ & G & $\mathrm{L}$ \\
\hline \multicolumn{10}{|l|}{ Combretaceae } \\
\hline Combretum hilarianum & $\mathrm{x}$ & $\mathrm{x}$ & & $\mathrm{x}$ & & $\mathrm{x}$ & & $\mathrm{V}$ & $\mathrm{L}$ \\
\hline \multicolumn{10}{|l|}{ Convolvulaceae } \\
\hline Daustinia montana & & & & $\mathrm{x}$ & & & $\mathrm{x}$ & $\mathrm{V}$ & $\mathrm{H}$ \\
\hline Ipomoea bahiensis & & $\mathrm{x}$ & & $\mathrm{x}$ & & $\mathrm{x}$ & & $\mathrm{V}$ & $\mathrm{H}$ \\
\hline Ipomoea brasiliana & $\mathrm{x}$ & $\mathrm{x}$ & $\mathrm{x}$ & & $\mathrm{x}$ & & & $\mathrm{V}$ & $\mathrm{L}$ \\
\hline Ipomoea grandifolia & $\mathrm{x}$ & & & & & & $\mathrm{x}$ & $\mathrm{V}$ & $\mathrm{H}$ \\
\hline Ipomoea hederifolia & & & & $\mathrm{x}$ & & & $\mathrm{x}$ & $\mathrm{V}$ & $\mathrm{L}$ \\
\hline Ipomoea longeramosa & $\mathrm{x}$ & & & & & & $\mathrm{x}$ & $\mathrm{V}$ & $\mathrm{H}$ \\
\hline Ipomoea marcellia & $\mathrm{x}$ & $\mathrm{x}$ & & & & $\mathrm{x}$ & & $\mathrm{V}$ & $\mathrm{L}$ \\
\hline
\end{tabular}




\begin{tabular}{|c|c|c|c|c|c|c|c|c|c|}
\hline \multirow{2}{*}{ Família/Espécie } & \multicolumn{4}{|c|}{ Localidade } & \multicolumn{3}{|c|}{ Ocorrência } & \multirow{2}{*}{ Asc. } & \multirow{2}{*}{ Hab. } \\
\hline & C.S & C.C & A.R & A.A & A & $\mathbf{O}$ & $\mathbf{R}$ & & \\
\hline Ipomoea nil & $\mathrm{x}$ & & & $\mathrm{x}$ & & $\mathrm{x}$ & & $\mathrm{V}$ & $\mathrm{H}$ \\
\hline Ipomoea pintoi & $\mathrm{x}$ & & $\mathrm{x}$ & & $\mathrm{x}$ & & & $\mathrm{V}$ & $\mathrm{L}$ \\
\hline Ipomoea piurensis & $\mathrm{x}$ & & & & & & $\mathrm{x}$ & $\mathrm{V}$ & $\mathrm{H}$ \\
\hline Ipomoea rosea & $\mathrm{x}$ & $\mathrm{x}$ & & & $\mathrm{x}$ & & & $\mathrm{V}$ & $\mathrm{H}$ \\
\hline Ipomoea setosa & $\mathrm{x}$ & & & & & & $\mathrm{x}$ & $\mathrm{V}$ & $\mathrm{L}$ \\
\hline Ipomoea subalata & $\mathrm{x}$ & & & & & $\mathrm{x}$ & & $\mathrm{V}$ & $\mathrm{L}$ \\
\hline Ipomoea subincana & $\mathrm{x}$ & $\mathrm{x}$ & $\mathrm{x}$ & $\mathrm{x}$ & & & $\mathrm{x}$ & $\mathrm{V}$ & $\mathrm{L}$ \\
\hline Jacquemontia chrysanthera & $\mathrm{x}$ & & $\mathrm{x}$ & & & $\mathrm{x}$ & & $\mathrm{V}$ & $\mathrm{L}$ \\
\hline Jacquemontia corymbulosa & $\mathrm{x}$ & $\mathrm{x}$ & $\mathrm{x}$ & $\mathrm{x}$ & & & $\mathrm{x}$ & $\mathrm{V}$ & $\mathrm{L}$ \\
\hline Jacquemontia evolvuloides & & & & $\mathrm{x}$ & & $\mathrm{x}$ & & $\mathrm{V}$ & $\mathrm{H}$ \\
\hline Jacquemontia mucronifera & $\mathrm{x}$ & & $\mathrm{x}$ & & & $\mathrm{x}$ & & $\mathrm{V}$ & $\mathrm{L}$ \\
\hline Jacquemontia nodiflora & & $\mathrm{x}$ & & & & $\mathrm{x}$ & & $\mathrm{V}$ & $\mathrm{L}$ \\
\hline Jacquemontia pentanthos & & $\mathrm{x}$ & & & & & $\mathrm{x}$ & $\mathrm{V}$ & $\mathrm{L}$ \\
\hline Merremia aegyptia & & & & $\mathrm{x}$ & & & $\mathrm{x}$ & $\mathrm{V}$ & $\mathrm{L}$ \\
\hline Merremia cissoides & & & & $\mathrm{x}$ & & & $\mathrm{x}$ & $\mathrm{V}$ & $\mathrm{H}$ \\
\hline Turbina cordata & & $\mathrm{x}$ & $\mathrm{x}$ & & & & $\mathrm{x}$ & $\mathrm{V}$ & $\mathrm{L}$ \\
\hline \multicolumn{10}{|l|}{ Cucurbitaceae } \\
\hline Apodanthera congestiflora & $\mathrm{x}$ & $\mathrm{x}$ & & & & $\mathrm{x}$ & & $\mathrm{G}$ & $\mathrm{H}$ \\
\hline Apodanthera glaziovii & $\mathrm{x}$ & & & & & $\mathrm{x}$ & & G & $\mathrm{H}$ \\
\hline Cayaponia martiana & $\mathrm{x}$ & & & & & & $\mathrm{x}$ & G & $\mathrm{H}$ \\
\hline Cayaponia tayuya & & $\mathrm{x}$ & & $\mathrm{x}$ & & & $\mathrm{x}$ & G & $\mathrm{H}$ \\
\hline Citrullus lanatus & & & & $\mathrm{x}$ & & & $\mathrm{x}$ & G & $\mathrm{H}$ \\
\hline Cucumis anguria & & & & $\mathrm{x}$ & & & $\mathrm{x}$ & $\mathrm{G}$ & $\mathrm{H}$ \\
\hline Momordica charantia & & $\mathrm{x}$ & & $\mathrm{x}$ & & $\mathrm{x}$ & & G & $\mathrm{H}$ \\
\hline \multicolumn{10}{|l|}{ Dioscoreaceae } \\
\hline Dioscorea cinnamomifolia & $\mathrm{x}$ & $\mathrm{x}$ & $\mathrm{x}$ & $\mathrm{x}$ & $\mathrm{x}$ & & & $\mathrm{V}$ & $\mathrm{H}$ \\
\hline Dioscorea leptostachya & & & & $\mathrm{x}$ & & & $\mathrm{x}$ & $\mathrm{V}$ & $\mathrm{H}$ \\
\hline Dioscorea piperifolia & & & $\mathrm{x}$ & $\mathrm{x}$ & & & $\mathrm{x}$ & $\mathrm{V}$ & $\mathrm{H}$ \\
\hline Dioscorea subhastata & & & & & & & $\mathrm{x}$ & V & $\mathrm{H}$ \\
\hline \multicolumn{10}{|l|}{ Euphorbiaceae } \\
\hline Dalechampia schenckiana & $\mathrm{x}$ & $\mathrm{x}$ & $\mathrm{x}$ & $\mathrm{x}$ & $\mathrm{x}$ & & & $\mathrm{V}$ & $\mathrm{H}$ \\
\hline Tragia volubilis & & & & & & $\mathrm{x}$ & & $\mathrm{V}$ & $\mathrm{H}$ \\
\hline \multicolumn{10}{|l|}{ Fabaceae } \\
\hline Ancistrotropis peduncularis & $\mathrm{x}$ & & & & & & $\mathrm{x}$ & $\mathrm{V}$ & $\mathrm{H}$ \\
\hline Canavalia brasiliensis & & & & $\mathrm{x}$ & & & $\mathrm{x}$ & $\mathrm{V}$ & $\mathrm{L}$ \\
\hline Centrosema arenarium & $\mathrm{x}$ & & & $\mathrm{x}$ & & $\mathrm{x}$ & & $\mathrm{V}$ & $\mathrm{H}$ \\
\hline Centrosema brasilianum & & & & $\mathrm{x}$ & $\mathrm{x}$ & & & $\mathrm{V}$ & $\mathrm{H}$ \\
\hline Centrosema coriaceum & $\mathrm{x}$ & & & $\mathrm{x}$ & & $\mathrm{x}$ & & $\mathrm{V}$ & $\mathrm{H}$ \\
\hline Centrosema pubescens & & & & & & & & $\mathrm{V}$ & $\mathrm{H}$ \\
\hline Chaetocalyx scandens var. pubescens & $\mathrm{x}$ & & $\mathrm{x}$ & $\mathrm{x}$ & $\mathrm{x}$ & & & $\mathrm{V}$ & $\mathrm{H}$ \\
\hline Dioclea grandiflora & $\mathrm{x}$ & $\mathrm{x}$ & & $\mathrm{x}$ & $\mathrm{x}$ & & & $\mathrm{V}$ & $\mathrm{L}$ \\
\hline Macroptilium bracteatum & & & & $\mathrm{x}$ & & & $\mathrm{x}$ & $\mathrm{V}$ & $\mathrm{H}$ \\
\hline
\end{tabular}




\begin{tabular}{|c|c|c|c|c|c|c|c|c|c|}
\hline \multirow{2}{*}{ Família/Espécie } & \multicolumn{4}{|c|}{ Localidade } & \multicolumn{3}{|c|}{ Ocorrência } & \multirow{2}{*}{ Asc. } & \multirow{2}{*}{ Hab. } \\
\hline & C.S & C.C & A.R & A.A & $\mathbf{A}$ & $\mathbf{O}$ & $\mathbf{R}$ & & \\
\hline Macroptilium martii & & & & $\mathrm{x}$ & & & $\mathrm{x}$ & $\mathrm{V}$ & $\mathrm{H}$ \\
\hline Periandra coccinea & $\mathrm{x}$ & & & $\mathrm{x}$ & & $\mathrm{x}$ & & $\mathrm{V}$ & $\mathrm{L}$ \\
\hline Vigna luteola & & & & $\mathrm{x}$ & & & $\mathrm{x}$ & $\mathrm{V}$ & $\mathrm{H}$ \\
\hline \multicolumn{10}{|l|}{ Loganiaceae } \\
\hline Strychnos gardneri & $\mathrm{x}$ & & & & & & $\mathrm{x}$ & $\mathrm{G}$ & $\mathrm{L}$ \\
\hline Strychnos rubiginosa & $\mathrm{x}$ & & & $\mathrm{x}$ & $\mathrm{x}$ & & & $\mathrm{G}$ & $\mathrm{L}$ \\
\hline \multicolumn{10}{|l|}{ Malpighiaceae } \\
\hline Banisteriopsis muricata & $\mathrm{x}$ & & & $\mathrm{x}$ & $\mathrm{x}$ & & & $\mathrm{V}$ & $\mathrm{L}$ \\
\hline Banisteriopsis stellaris & $\mathrm{x}$ & & $\mathrm{x}$ & $\mathrm{x}$ & $\mathrm{x}$ & & & $\mathrm{V}$ & $\mathrm{H}$ \\
\hline Carolus chasei & $\mathrm{x}$ & & & & & & $\mathrm{x}$ & $\mathrm{V}$ & $\mathrm{L}$ \\
\hline Diplopterys lutea & & & & $\mathrm{x}$ & & & $\mathrm{x}$ & $\mathrm{V}$ & $\mathrm{L}$ \\
\hline Diplopterys pubipetala & $\mathrm{x}$ & & $\mathrm{x}$ & & $\mathrm{x}$ & & & $\mathrm{V}$ & $\mathrm{L}$ \\
\hline Heteropterys byrsonimifolia & $\mathrm{x}$ & & $\mathrm{x}$ & & & & $\mathrm{x}$ & $\mathrm{V}$ & $\mathrm{L}$ \\
\hline Heteropterys caducibracteata & & & $\mathrm{x}$ & & & & $\mathrm{x}$ & $\mathrm{V}$ & $\mathrm{L}$ \\
\hline Heteropterys trichanthera & & & & $\mathrm{x}$ & & & $\mathrm{x}$ & $\mathrm{V}$ & $\mathrm{L}$ \\
\hline Janusia anisandra & $\mathrm{x}$ & & $\mathrm{x}$ & & & $\mathrm{x}$ & & $\mathrm{V}$ & $\mathrm{L}$ \\
\hline Mascagnia sepium & $\mathrm{x}$ & & & & & & $\mathrm{x}$ & $\mathrm{V}$ & $\mathrm{L}$ \\
\hline Stigmaphyllon auriculatum & $\mathrm{x}$ & $\mathrm{x}$ & $\mathrm{x}$ & $\mathrm{x}$ & $\mathrm{x}$ & & & $\mathrm{V}$ & $\mathrm{H}$ \\
\hline \multicolumn{10}{|l|}{ Passifloraceae } \\
\hline Passiflora cincinnata & $\mathrm{x}$ & & & $\mathrm{x}$ & $\mathrm{x}$ & & & G & $\mathrm{L}$ \\
\hline Passiflora foetida & $\mathrm{x}$ & $\mathrm{x}$ & $\mathrm{x}$ & $\mathrm{x}$ & $\mathrm{x}$ & & & G & $\mathrm{H}$ \\
\hline Passiflora luetzelburgii & $\mathrm{x}$ & $\mathrm{x}$ & $\mathrm{x}$ & $\mathrm{x}$ & $\mathrm{x}$ & & & G & $\mathrm{L}$ \\
\hline Passiflora silvestris & $\mathrm{x}$ & & & & & & $\mathrm{x}$ & G & $\mathrm{L}$ \\
\hline \multicolumn{10}{|l|}{ Polygalaceae } \\
\hline Securidaca diversifolia & $\mathrm{x}$ & & & $\mathrm{x}$ & & & $\mathrm{x}$ & $\mathrm{V}$ & $\mathrm{L}$ \\
\hline \multicolumn{10}{|l|}{ Rhamnaceae } \\
\hline Gouania colurnifolia & $\mathrm{x}$ & & $\mathrm{x}$ & & & & $\mathrm{x}$ & G & $\mathrm{L}$ \\
\hline \multicolumn{10}{|l|}{ Sapindaceae } \\
\hline Cardiospermum corindum & $\mathrm{x}$ & $\mathrm{x}$ & $\mathrm{x}$ & $\mathrm{x}$ & $\mathrm{x}$ & & & G & $\mathrm{H}$ \\
\hline Serjania glabrata & $\mathrm{x}$ & $\mathrm{x}$ & & $\mathrm{x}$ & $\mathrm{x}$ & & & G & $\mathrm{L}$ \\
\hline Serjania lethalis & $\mathrm{x}$ & & & $\mathrm{x}$ & $\mathrm{x}$ & & & $\mathrm{G}$ & $\mathrm{L}$ \\
\hline Serjania marginata & $\mathrm{x}$ & $\mathrm{x}$ & & & & & $\mathrm{x}$ & G & $\mathrm{L}$ \\
\hline Serjania pernambucensis & $\mathrm{x}$ & & & & & & $\mathrm{x}$ & G & $\mathrm{L}$ \\
\hline Urvillea ulmacea & & & $\mathrm{x}$ & $\mathrm{x}$ & & & $\mathrm{x}$ & $\mathrm{G}$ & $\mathrm{H}$ \\
\hline \multicolumn{10}{|l|}{ Smilacaceae } \\
\hline Smilax campestris & $\mathrm{x}$ & & $\mathrm{x}$ & & & $\mathrm{x}$ & & $\mathrm{G}$ & $\mathrm{H}$ \\
\hline Smilax cissoides & $\mathrm{x}$ & & & $\mathrm{x}$ & & $\mathrm{x}$ & & $\mathrm{G}$ & $\mathrm{H}$ \\
\hline \multicolumn{10}{|l|}{ Trigoniaceae } \\
\hline Trigonia nivea & $\mathrm{x}$ & $\mathrm{x}$ & & & & $\mathrm{x}$ & & $\mathrm{V}$ & $\mathrm{L}$ \\
\hline \multicolumn{10}{|l|}{ Vitaceae } \\
\hline Cissus blanchetiana & $\mathrm{x}$ & & $\mathrm{x}$ & & & $\mathrm{x}$ & & G & $\mathrm{H}$ \\
\hline Cissus verticillata & & & & $\mathrm{x}$ & & & $\mathrm{x}$ & G & $\mathrm{H}$ \\
\hline
\end{tabular}


A. Juss - (Malpighiaceae); Passiflora silvestris Vell. - (Passifloraceae); Gouania colurnifolia Reissek - (Rhamnaceae); Urvillea ulmacea Kunth - (Sapindaceae) e Cissus verticillata (L.) Nicolson \& C.E. Jarvis - (Vitaceae) são conhecidas por apenas uma coleta na área. Uma possível razão para as mesmas não terem sido recoletadas, principalmente as herbáceas, foram os baixos índices pluviométricos nos anos 2012 e 2013, considerados os mais baixos nos últimos dez anos (SADMET/INMET 2013). Outra hipótese é que essas espécies estejam localmente extintas, visto que são coletas antigas e o PARNA do Catimbau sofre diariamente impactos antrópicos (e.g., agricultura de subsistência, pastagem, cultura extensiva e especulação imobiliária).

Convolvulaceae foi a família que apresentou o maior número de espécies consideradas endêmicas da Caatinga de acordo com BFG (2015) (Ipomoea marcellia Meisn., I. pintoi O'Donell, Jacquemontia chrysanthera Buril), seguida de Cucurbitaceae (Apodanthera congestiflora Cogn., A. glaziovii Cogn.), Malpighiaceae (Heteropterys caducibracteata), Fabaceae (Dioclea glandiflora Mart. ex Benth.), Euphorbiaceae (Dalechampia schenckiana Pax \& K.Hoffm.) e Apocynaceae (Mandevilla catimbauensis Souza-Silva et al. 2010). Juntas, correspondem a $11 \%$ de todas as espécies encontradas no PARNA Catimbau. Mandevilla catimbauensis é uma espécie que só tem registro no PARNA Catimbau (Souza-Silva et al. 2010), conhecida até o momento apenas na localidade típica. Neste trabalho estão sendo apresentados novos registros de populações em localidades distintas no Parque. Foram também localizadas novas populações de J. chysanthera, recentemente descrita (Buril \& Alves 2011), e limitada a poucos registros nos estados de Pernambuco e Bahia.

Dalechampia schenckiana (Euphorbiaceae) é uma das trepadeiras mais abundantes no PARNA Catimbau e restrita ao estado de Pernambuco (BGF 2015; Webster \& Armbruster 1991). As amostras disponíveis da espécie nos herbários são poucas e provenientes de Buíque ou regiões próximas. Pax \& Hoffmann (1919) indicaram como localidade típica a cidade de Garanhuns. É importante ressaltar que em 1887, quando a espécie foi coletada, a área do PARNA Catimbau era distrito de Garanhuns (IBGE 2013), isso pode sugerir que a espécie seja restrita a essa região.

Constatou-se a ocorrência de mais de um tipo de mecanismo de ascensão entre as espécies no PARNA Catimbau. As que apresentam caule volúvel representam $68 \%$ e as que utilizam gavinhas correspondem a 32\% (Tab. 1). Em outros domínios fitogeográficos a volubilidade também foi o principal meio de adaptação, contudo não ultrapassavam $60 \%$ das espécies. Na Mata Atlântica, variou de 43\%-51\% (Tibiriçá et al. 2006; Santos 2009; Durigon et al. 2009; Villagra \& Romaniuc-Neto 2010) e no Cerrado foi de $60 \%$ (Weiser \& Godoy 2001). Com base nos inventários anteriormente citados, as espécies com gavinhas correspondem a 34-42\% na Mata Atlântica e 40\% no Cerrado. Os mesmos trabalhos indicaram outros modos de escaladas (apoiantes, raízes adventícias, escandentes ou por espinhos) não observados na área de estudo.

A maior parte das espécies, no PARNA Catimbau, foi considerada rara localmente (42\%), visto o alto índice de espécies não recoletadas ou coletadas apenas uma vez. Contudo, são espécies amplamente distribuídas no Brasil e que na área de estudo ocorreram principalmente em áreas antropizadas. As ocasionais corresponderam a $33 \%$ e as abundantes a $25 \%$ e estão distribuídas principalmente nas Caatingas arenosa e pedregosa (Tab. 1).

Considerando-se os dados disponíveis em BFG (2015), quatro novas ocorrências no estado de Pernambuco foram registradas: Mikania micrantha Kunth (Asteraceae), Ancistrotropis peduncularis (Kunth) A. Delgado, Vigna luteola (Jacq.) Benth (Fabaceae) e Heteropterys caducibracteata (Malpighiaceae). Dois novos registros são apresentados para a flora da Caatinga: Dioscorea subhastata Vell. (Dioscoreaceae) e Passiflora silvestris (Passifloraceae). Outras três espécies são registros novos tanto na Caatinga quanto em Pernambuco: Marsdenia hilariana E.Fourn. (Apocynaceae), Dioscorea cinnamomifolia Hook. (Dioscoreaceae) e Heteropeterys byrsonimifolia A. Juss. (Malpighiaceae).

As trepadeiras do PARNA Catimbau correspondem a $40 \%$ das espécies citadas no Semiárido do estado de Pernambuco (Cruz et. al. 2010). Este valor reafirma a importância da diversidade do Parque, o qual foi criado por apresentar extrema importância biológica (Sampaio et al. 2002). Com esse estudo foi possível detectar a escassez de informações florísticas e taxonômicas relacionadas às trepadeiras da Caatinga. Vale ressaltar que este é o primeiro trabalho taxonômico realizado neste domínio fitogeográfico. 
Chave de identificação para as plantas trepadeiras ocorrentes no Parque Nacional do Catimbau

1. Folhas compostas com mais de 3 folíolos.

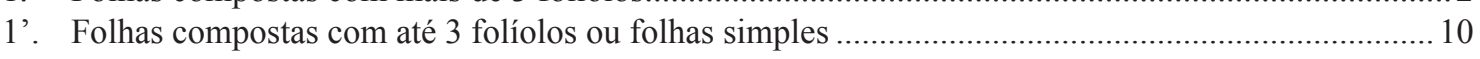

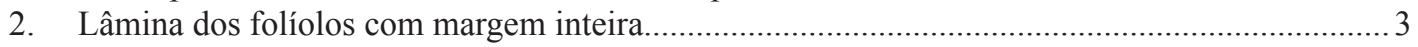

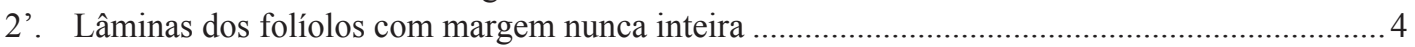

3. Ramos pubescentes; folhas pinadas e imparipinadas; estípulas presentes.

66. Chaetocalyx scandens var. pubescens

3'. Ramos hirsutos; folhas palmadas (Fig. 2a); estípulas ausentes. 44. Merremia aegyptia 4. Lâmina foliar glabra 93. Serjania lethalis

4'. Lâmina foliar com indumento

5. Folíolos com raque alada (Fig. 2b)...................................94. Serjania marginata

5'. Folíolos com raque nunca alada.

6. Folhas palmadas com tricomas glandulares restritos à margem

45. Merremia cissoides

6'. Folhas pinadas e sem tricomas glandulares.

7. Inflorescência umbeliforme; fruto baga ..........100. Cissus blanchetiana

7'. Inflorescência em tirso; fruto cápsula ou esquizocárpico.

8. Inflorescência com 4-6 ramos secundários reunidos no ápice da raque (Fig. 2c); fruto cápsula inflada.

91. Cardiospermum corindum

8'. Inflorescência com mais de 10 ramos secundários distribuídos ao longo da raque (Fig. 2d); fruto esquizocárpico samaróide.

9. Folíolos lanceolados a oblongos ou ovais, face abaxial pubescente e indumento ferrugíneo.

95. Serjania pernambucensis

9'. Folíolos ovais a romboides com a face abaxial velutina e indumento esbranquiçado

92. Serjania glabrata

10. Folhas opostas

10'. Folhas alternas

11. Lâmina foliar glabrescente a glabra, as vezes com tricomas na margem.

11'. Lâmina foliar pilosa, lanosa, pubescente ou serícea

12. Profilos escamiformes, conspícuos (Fig. 2e)...

16. Bignonia ramentacea

12'. Profilos orbiculares a ovais, triangulares, diminutos ou ausentes.

13. Folhas compostas

13'. Folhas simples

14. Lâmina foliar com margem revoluta; profilos orbiculares a ovais, conspícuos (Fig. 2f)

15. Anemopaegma laeve

14'. Lâmina foliar com margem plana; profilos triangulares, diminutos ou ausentes

15. Base do pecíolo glabra; corola alva. 19. Fridericia limae

15'. Base do pecíolo com tricomas; corola alaranjada ou roxa a magenta. 
16. Pecíolo canaliculado (Fig. 2g), piloso apenas ao longo do sulco; corola alaranjada

16'. Pecíolo cilíndrico (Fig. 2h), pubescente; corola roxa a magenta.

17. Lâmina foliar com venação trinérvea (Fig. 2i)

17'. Lâmina foliar com venação peninérvea

18. Sépalas com elaióforos (Fig. 2j); frutos alados.

18'. Sépalas sem elaióforos; frutos não alados.

19. Pecíolo com um par de glândulas no ápice (Fig. 2k); folhas membranáceas

84. Stigmaphyllon auriculatum

19'. Pecíolo eglandular; folhas cartáceas a coriáceas

20. Folhas elípticas, base cuneada.

79. Heteropterys byrsonimifolia

20 '. Folhas obovais a ovais ou elípticas a ovais, base foliar subcordada a arredondada

21. Folhas obovais a ovais com margem revoluta.

78. Diplopterys pubipetala

21 '. Folhas elípticas a ovais com margem plana 75. Banisteriopsis stellaris

22. Folhas lineares com $<3 \mathrm{~mm}$ larg. (Fig. 21) 4. Ditassa capillaris

22 '. Folhas não lineares $\geq 3 \mathrm{~mm}$ larg. .23

23. Folhas hastadas a triangulares (Fig. 2m,n) ........5. Ditassa hastata

23'. Folhas elípticas, lanceoladas, ovais, elípticas a oblongas ou orbiculares a ovais....

24. Coléteres ausentes

24'. Coléteres no pecíolo, na base da lâmina foliar, nos nós, no pedúnculo ou no pedicelo.

25. Folhas orbiculares a ovais, ápice retuso a obtuso (Fig. 2o)

7. Ditassa rotundifolia

25'. Folhas ovais ou elípticas, ápice acuminado a agudo

26. Folhas ovais, base cordada a oblíqua, margem ciliada; inflorescência em capítulo; fruto cipsela

1. Mikania micrantha

26'. Folhas elípticas, base cuneada, margem não ciliada; inflorescência glomeruliforme; fruto folículo

10. Marsdenia hilariana

27. Ápice cuspidado; corola esverdeada.

3. Blepharodon pictum

27'. Ápice agudo; corola amarela ou roxa .28

28. Corola amarela; fruto $>15 \mathrm{~cm}$ compr., sementes oblongo-compressas, com duas alas laterais, sem tricomas 13. Skytanthus hancorniifolius

28'. Corola roxa; fruto $\leq 12 \mathrm{~cm}$ compr., sementes lineares, sem alas laterais, com tricomas longos no ápice

\section{Mandevilla catimbauensis}

29. Folhas compostas 30

29'. Folhas simples 33

30. Lâmina foliar com margem denteada 20. Fridericia parviflora

30'. Lâmina foliar com margem inteira 
31. Lâmina foliar com margem revoluta; profilos orbiculares a ovais

15. Anemopaegma laeve

31'. Lâmina foliar com margem plana; profilos triangulares, lineares, às vezes caducos 32

32. Folíolos ovais a lanceolados; inflorescência em cimeira com brácteas lineares, persistentes; lacínios do cálice longos $>2,5 \mathrm{~mm}$ compr. (Fig. $2 \mathrm{p}$ ) 17. Cuspidaria aff. lateriflora

32'. Folíolos oblongos a oblanceolados; inflorescência em racemo com um par de brácteas triangulares, caducas; lacínios do cálice curtos $\leq 1 \mathrm{~mm}$ compr. (Fig. 2q).

18. Fridericia dichotoma

33. Nervuras secundárias da face abaxial da folha proeminentes...

33'. Nervuras secundárias da face abaxial da folha não proeminentes 38

34. Base foliar cordada; coléteres na base do pecíolo e ao longo da nervura principal da face abaxial (Fig. 2r)

9. Mandevilla scabra

34'. Base foliar obtusa a subcordada, cuneada ou arredondada a cordada; coléteres ausentes

35. Pecíolo com glândulas.

74. Banisteriopsis muricata

35'. Pecíolo eglandular. 36

36. Estípulas ausentes

23. Combretum hilarianum

36'. Estípulas presentes 37

37. Base foliar cuneada, face abaxial lanosa com tricomas esbranquiçados; corola alva; fruto cápsula septicida 99. Trigonia nivea

37'. Base foliar arredondada ou cordada, face abaxial pilosa com tricomas ferrugíneos; corola amarela; fruto sâmara. 83. Mascagnia sepium 38. Coléteres nos nós, pecíolo, pedicelo ou sépalas (Fig. 3a)

38'. Coléteres ausentes 39

39. Pecíolo glandular 40

39'. Pecíolo eglandular.

40. Lâmina foliar jovem e madura com face adaxial glabrescente a glabra; pedicelo $<6 \mathrm{~mm}$ compr.; cálice com elaióforo. 76. Carolus chasei

40'. Lâmina foliar jovem com face adaxial lanosa (glabrescente a glabra na maturidade); pedicelo $>1 \mathrm{~cm}$ compr.; cálice sem elaióforo . 77. Diplopterys lutea

41. Lâmina foliar adaxial glabrescente a glabra, às vezes com tricomas na margem.

75. Banisteriopsis stellaris

41'. Lâmina foliar adaxial pubescente, lanosa, vilosa, pilosa, tomentosa ou hirsuta . 42

42. Folhas sésseis ou com pecíolo $<6 \mathrm{~mm}$ compr.

42'. Folhas com pecíolo $>1 \mathrm{~cm}$ compr. 43

73. Strychnos rubiginosa

43'. Lâmina foliar com venação peninérvea...

44

44. Folhas com base cordada a truncada ou cordada a arredondada ou obtusa

44'. Folhas com base cuneada.............. 46

45. Folhas ovais; inflorescência em panícula; corola amarela; sépalas com elaióforos; fruto sâmara ... 82. Janusia anisandra 
45'. Folhas elípticas a ovais; inflorescência em umbeliforme; corola violácea; sépalas sem elaióforos; fruto folículo. 14. Temnadenia violacea

46. Ápice foliar mucronado; flores alvas; sépalas sem elaióforos

6. Ditassa oxyphylla

46'. Ápice foliar não mucronado; flores amarelas ou rosas; sépalas com elaióforos.

47. Lâmina foliar com face adaxial pilosa; glândulas esparsas ao longo da margem na face abaxial da folha. 81. Heteropterys trichanthera

47'. Lâmina foliar com face adaxial glabrescente a glabra; glândulas ausentes ao longo da margem foliar. 80. Heteropterys caducibracteata

48. Ramos hirsutos; lâmina foliar $>4 \mathrm{~cm}$ larg.; flores pediceladas com corola alva; frutos lisos 12. Schubertia multiflora

48'. Ramos pubescentes; lâmina foliar $<3 \mathrm{~cm}$ larg.; flores sésseis a subsésseis com corola castanha a vinácea; frutos tuberculados (Fig. 3b)

11. Matelea maritima

49. Lâmina foliar com margem não inteira

49'. Lâmina foliar com margem inteira a sinuosa; às vezes com 1 a 3 dentes ao longo da margem. 66

50. Tricomas glandulares nas folhas e nas estípulas 86. Passiflora foetida

50'. Tricomas glandulares ausentes . .51

51. Folhas simples inteiras ou compostas com folíolos inteiros .... 52

51'. Folhas simples lobadas a partidas ou compostas com folíolos lobados..

52. Folhas compostas; fruto cápsula inflada na região central, alada.... 96. Urvillea ulmacea

52'. Folhas simples; fruto baga, cápsula não alada ou esquizocárpico... 53

53. Tricomas restritos às nervuras na face abaxial da lâmina foliar; inflorescência em panícula de umbela; fruto baga 101. Cissus verticillata

53'. Tricomas em toda lâmina foliar; inflorescência em cimeira capituliforme, racemo ou pseudanto; fruto cápsula ou esquizocárpico 54

54. Ramos e folhas lanosas; inflorescência em cimeira capituliforme; flores amarelas

24. Daustinia montana

54'. Ramos pubescentes, velutinos ou hirsustos, folhas pilosas, pubescentes, glabrescentes ou glabras; inflorescência em racemo ou pseudanto; flores verde-amareladas ou alvas.

55. Inflorescência em pseudanto; (Fig. 3c)

58. Dalechampia schenckiana

55'. Inflorescência em racemo 56

56. Folhas velutinas com tricomas não urticantes; glândulas na margem da lâmina foliar na face abaxial. 90. Gouania colurnifolia

56'. Folhas pilosas a hirsutas com tricomas urticantes; glândulas ausentes na margem da lâmina foliar. 59. Tragia volubilis

57. Folhas simples 5-partidas; pecíolo com um par de glândulas; corola violácea; corona presente. 85. Passiflora cincinnata

57'. Folhas compostas ou simples lobadas; pecíolo eglandular; corola amarela, esverdeada ou rosa; corona ausente..... 58 
58. Ramos lanosos

58'. Ramos glabros, glabrescentes, pilosos, hirsutos, híspidos ou pubescentes

59. Ramos com tricomas longo-lanosos; folhas com mais de 10 lobos (Fig. 3d)

51. Citrullus lanatus

59'. Ramos com tricomas curto-lanosos; folhas com menos de 5 lobos.

24. Daustinia montana

60. Lâmina foliar glabra

35. Ipomoea setosa

60'. Lâmina foliar com tricomas 61

61. Inflorescência séssil a subséssil (Fig. 3e).

47. Apodanthera congestiflora

61'. Inflorescência pedunculada, quando flor solitária, pedicelada

62. Lâmina foliar inteira a levemente lobada, base cordada

48. Apodanthera glaziovii

62'. Lâmina profundamente lobada (3-7 lobos), base não cordada.

63. Ápice dos lobos foliares laterais agudo

53. Momordica charantia

63'. Ápice dos lobos foliares laterais arredondado ou assimétrico

64. Inflorescência com até 5 flores

52. Cucumis anguria

64'. Inflorescência com mais de10 flores

65. Base foliar decurrente com glândulas na base da folha (Fig. 3f) ....

50. Cayaponia tayuya

65'. Base foliar não decurrente sem glândulas na base da folha

49. Cayaponia martiana

66. Folhas compostas com até 3 folíolos

67

66'. Folhas simples inteiras ou lobadas 78

67. Lâmina foliar glabra, às vezes com margem ciliada .68

67'. Lâmina foliar (ver ambas as faces) glabrescente, pilosa, lanosa, pubescente, vilosa ou pubérula 69

68. Folhas coriáceas; ápice da lâmina foliar emarginado; presença de estípula ......64. Centrosema coriaceum

68'. Folhas membranáceas; ápice da lâmina foliar agudo e mucronado; ausência de estípulas

34. Ipomoea rosea

69. Pedúnculo e raque da inflorescência $>8 \mathrm{~cm}$ compr. .70

69'. Pedúnculo e raque da inflorescência $\leq 5 \mathrm{~cm}$ compr. .75

70. Folíolos deltoides (Fig. 3g), ovais a lanceolados, (Fig. 3h), suborbiculares a ovais (Fig. 3i), assimétricos (Fig. 3j), lanceolados assimétricos.

70'. Folíolos ovais a elípticos (Fig. 3k), obovais a suborbiculares (Fig. 31), elípticos assimétricos ou ovais (Fig. $3 \mathrm{~m}$ ) ............ 73

71. Base do pedúnculo com fascículo de brácteas (Fig. 3n) 68. Macroptilium bracteatum

71'. Base do pedúnculo sem fascículo de brácteas

72. Folíolos suborbiculares a ovais ou assimétricos, vilosos; dentes do cálice mais longos que o tubo; alas vermelhas; frutos falcados $\leq$ $3 \mathrm{~cm}$ compr. 
72'. Folíolos assimétricos, deltoides ou ovais a lanceolados, pubescentes a glabrescentes; dentes do cálice mais curtos que o tubo; alas lilases; frutos lineares $\geq 5 \mathrm{~cm}$ compr......60. Ancistrotropis peduncularis

73. Lâmina do folíolo com $\leq 2,5 \mathrm{~cm}$ larg.; corola vermelha; inflorescência com até 5 flores

70. Periandra coccinea

73'. Lâmina do folíolo com $>4 \mathrm{~cm}$ larg.; corola roxa; inflorescência com mais de10 flores 74

74. Lâmina foliar com face adaxial vilosa, ápice arredondado, às vezes agudo e mucronado; cálice com 5 dentes, viloso; fruto viloso com margem arqueada (Fig. 3o)

67. Dioclea grandiflora

74'. Lâmina foliar com face adaxial glabrescente a glabra, ápice agudo; cálice com 4 dentes, piloso; fruto pubescente com margem plana...

61. Canavalia brasiliensis

75. Ramos hirsutos; brácteas $<1,5 \mathrm{~mm}$ larg.; corola amarela.

71. Vigna luteola

75'. Ramos glabros ou pubescentes a pilosos; brácteas $>3 \mathrm{~mm}$ larg.; flores roxas

76. Ao menos um dente do cálice maior que o comprimento do tubo (Fig. 3p)

62. Centrosema arenarium

76'. Todos os dentes do cálice menores ou iguais ao comprimento do tubo. 77

77. Bractéolas $<10 \mathrm{~mm}$. compr.; inflorescência com 2 ou mais flores; fruto pubescente

65. Centrosema pubescens

77'. Bractéolas $>10 \mathrm{~mm}$; compr.; flor solitária; fruto glabro

63. Centrosema brasilianum

78. Pecíolo com glândulas ao longo da sua extensão ou apenas na inserção do ramo

78'. Pecíolo eglandular.....

79. Estípula $>1 \mathrm{~cm}$ compr.; corola branca .......88. Passiflora silvestris

79'. Estípula, quando presente, $<5 \mathrm{~mm}$ compr.; corola vermelha ou lilás

80

80. Glândulas na região mediano-basal do pecíolo; flores solitárias, corola vermelha; fruto baga.

87. Passiflora luetzelburgii

80'. Glândula na inserção do pecíolo no ramo (Fig. 3q); inflorescência em racemo; corola lilás; fruto sâmara

89. Securidaca diversifolia

81. Lâmina foliar com venação trinérvea; flores inconspícuas

$<8 \mathrm{~mm}$ compr.

82

81'. Lâmina foliar com venação peninérvea; flores conspícuas $\geq 1,5 \mathrm{~cm}$ compr.

82. Ramos armados; gavinhas presentes; inflorescência em umbela; fruto baga

82'. Ramos inermes; gavinhas ausentes; inflorescência em espiga ou racemo; fruto cápsula ..... 84

83. Folhas coriáceas, com $3-5$ nervuras proeminentes na face abaxial 97. Smilax campestris

83'. Folhas membranáceas a cartáceas, com 7 ou mais nervuras proeminentes na face abaxial ... 98. Smilax cissoides

84. Flores estaminadas sésseis (Fig. 3r) em espiga; flores pistiladas com tépalas unguiculadas

55. Dioscorea leptostachya

84'. Flores estaminadas pediceladas em racemo; flores pistiladas com tépalas não unguiculadas 
85. Flor estaminada com três estames soldados à coluna carnosa (Fig. 3s); inflorescência pistilada com duas flores por nó, tépalas multinervadas

85'. Flor estaminada com seis estames livres; inflorescência pistilada com uma flor por nó, tépalas univervadas ou 3-nervadas

86. Sinus da base foliar estreito $<3 \mathrm{~mm}$; tricomas na inserção do pecíolo no ramo

54. Dioscorea cinnamomifolia

86'. Sinus da base foliar amplo $>1 \mathrm{~cm}$; sem tricomas na inserção do pecíolo no ramo.

56. Dioscorea piperifolia

87. Ramos e/ou lâmina foliar com tricomas estrelados (Fig. 3u).

87'. Ramos e/ou lâmina foliar glabros ou com tricomas não estrelados

88. Ramos com tricomas glandulares.

40. Jacquemontia evolvuloides

88'. Ramos sem tricomas glandulares

89. Tricomas com 5(-7) braços armados; anteras amareladas

38. Jacquemontia chrysanthera

89'. Tricomas com 3 braços armados; anteras brancas

90. Inflorescência com bractéolas iguais ou maiores que as sépalas externas

(Fig. 3t)

90'. Inflorescência com bractéolas menores que as sépalas externas

91. Ramos densamente pubescentes; bractéolas lineares

41. Jacquemontia mucronifera

91'. Ramos velutinos a glabrescentes; bractéolas lanceoladas ou oblanceoladas

43. Jacquemontia pentanthos

92. Sépalas desiguais entre si, as externas elípticas a lanceoladas, pubescentes; corola completamente azul.

39. Jacquemontia corymbulosa

92'. Sépalas subiguais entre si, rotundas, pubescentes a glabrescentes na base; corola branca com fauce vinácea

42. Jacquemontia nodiflora

93. Ramos glabrescentes a glabros.

93'. Ramos pubescentes, hirsutos, vilosos ou lanosos...

94. Folhas elípticas a oblanceoladas; sépalas iguais entre si.

32. Ipomoea pintoi

94'. Folhas sagitadas ou cordadas; sépalas desiguais entre si

95. Sépalas externas com rostro subapical ou arista.......

95'. Sépalas externas sem rostro subapical ou arista .......

97

96. Sépalas com rostro subapical $\leq 1 \mathrm{~mm}$ compr.; corola infundibuliforme, roxa.

25. Ipomoea bahiensis

96'. Sépalas com arista $>2,5 \mathrm{~mm}$ compr.; corola hipocrateriforme, vermelha.

28. Ipomoea hederifolia

97. Pedicelo $\leq 5 \mathrm{~mm}$ compr.

33. Ipomoea piurensis

97'. Pedicelo $\geq 1 \mathrm{~cm}$ compr.

36. Ipomoea subalata

98. Sépalas externas iguais às internas ..

98'. Sépalas externas diferentes das internas. 101 
99. Folhas sem múcron; sépalas com ápice caudado, densamente hirsutas na base 31. Ipomoea nil

99'. Folhas com múcron; sépalas com ápice agudo ou apiculado, ciliadas ou glabrescentes. 100

100. Folhas inteiras a 3-lobadas; sépalas ciliadas; corola completamente rosa

27. Ipomoea grandifolia

100’. Folhas 5-lobadas; sépalas não ciliadas; corola amarela com fauce vinácea

29. Ipomoea longeramosa

101. Corola branco-amarelada; estames exsertos 30. Ipomoea marcellia

101 '. Corola rosa; estames insertos 102

102. Sépalas externas levemente maiores que as internas, glabrescentes a glabras

26. Ipomoea brasiliana

102'. Sépalas externas menores que as internas, pubescentes a vilosas 103

103. Lâmina foliar com a face adaxial glabrescente com tricomas restritos às nervuras (Fig. 3c); sépalas externas e internas pubescentes; mesopétala vilosa; fruto indeiscente.... 46. Turbina cordata

103'. Lâmina foliar com face adaxial densamente vilosa; sépalas externas vilosas e internas glabrescentes a glabra; mesopétala glabra; fruto deiscente

37. Ipomoea subincana

Asteraceae Bercht. \& J.Presl.

1. Mikania micrantha Kunth, Nov. Gen. Sp. (folio ed.) 4: 105. 1820[1818].

É a única trepadeira no PARNA Catimbau com ramos glabrescentes a glabros, folhas ovais, glabrescentes a glabras, margem ciliada, ápice agudo a acuminado, base cordada a oblíqua, inflorescência em capítulo (5 flores) e fruto cipsela. Floração e frutificação na estação seca.

Material examinado: Buíque, Quixel, 9.VIII.2012, fl., G.C. Delgado-Junior et al. 425 (UFP); Trilha da Pedra da Concha, 23.XI.2005, fr., Bocage et al. 1100 (IPA, HUEFS).

Apocynaceae Juss.

2. Blepharodon manicatum (Decne.) Fontella, Bradea 5(23): 262. 1989.

Fig. 3a

Diferencia-se das demais trepadeiras do PARNA Catimbau pelos ramos glabros, folhas lanceoladas, pubescentes, ápice agudo, mucronado e base cordada. A flor apresenta corola alva com manchas vináceas internamente e coléteres com comprimento superior a $3 \mathrm{~mm}$ nos nós, pecíolo, pedicelo e nas sépalas. Floração na estação chuvosa e frutificação não observada.

Material examinado: Buíque, Serra do Catimbau, 19.VI.1994, fl., A. Miranda et al. 1819 (HST, PEUFR); 25.II.2002. fl., Lopes et al. (UFP 31783).

\section{Blepharodon pictum (Vahl) W.D. Stevens,} Novon 10(3): 242. 2000.

É reconhecida no PARNACatimbau pelos ramos glabros, folhas elípticas, glabras, ápice cuspidado, base cuneada, coléteres nos nós e no pecíolo próximo a base foliar e corola esverdeada. Floração nas duas estações e frutificação na estação chuvosa.
Material examinado: Buíque, Brejo São José, 16.I.2013, fl., G.C. Delgado-Junior et al. 602 (HST, HUFS, UFP); Estrada para o Catimbau, 18.V.2005, bt., fl. e fr., Figueiredo et al. 39 (PEUFR).

4. Ditassa capillaris E. Fourn., in Mart. \& Eichler, Fl. bras. 6(4): 253. 1885.

Fig. 21

É a única trepadeira do PARNA Catimbau com ramos glabros, folhas lineares, glabras com largura inferior a $3 \mathrm{~mm}$, flores com comprimento igual ou inferior a $2,5 \mathrm{~mm}$ e corola alva. Floração nas duas estações e frutificação na estação chuvosa. Material selecionado: Buíque, Pedra da Concha, 8.X.2012, fl., G.C. Delgado-Junior et al. 472 (UFP); Serra de Jerusalém, 30.V.2012, fl. e fr., Delgado Junior et al. 310 (UFP).

\section{Ditassa hastata Decne., in A.DC., Prod. 8: 575.} 1844.

Fig. $2 \mathrm{~m}, \mathrm{n}$

É a única no PARNA Catimbau com ramos glabros, folhas hastadas ou triangulares, glabras, ápice acuminado, base hastata a subaguda e corola alva. Floração na estação seca e a frutificação na estação chuvosa.

Material selecionado: Buíque, Fazenda Brejo de São José, 15.I.2013, fl. e fr., G.C. Delgado-Junior et al. 588 (HST, HUEFS, IPA, UFP).

6. Ditassa oxyphylla Turcz. Bull., Soc. Nat. Moscou 21(1): 260. 1848.

Distingue-se das demais espécies de trepadeiras do PARNA Catimbau pelos ramos pubescentes, folhas elípticas a oblanceoladas, pilosas, ápice acuminado a agudo, mucronado e base cuneada. A inflorescência é umbeliforme, 
pedúnculo inconspícuo, com 5 a 8 flores e corola alva. Floração na seca e frutificação não observada.

Material examinado: Buíque, Estrada Buíque-Catimbau, 10.VII.1995, fl., K. Andrade 119 (PEUFR, SPF).
7. Ditassa rotundifolia (Decne.) Baill. ex K.Schum., in Engl. \& Prantl, Naturl. Pflanzenfam. 4(2): 242. 1895.

Fig 2o

Diferencia-se das espécies do PARNA Catimbau pelos ramos pubescentes a glabrescentes
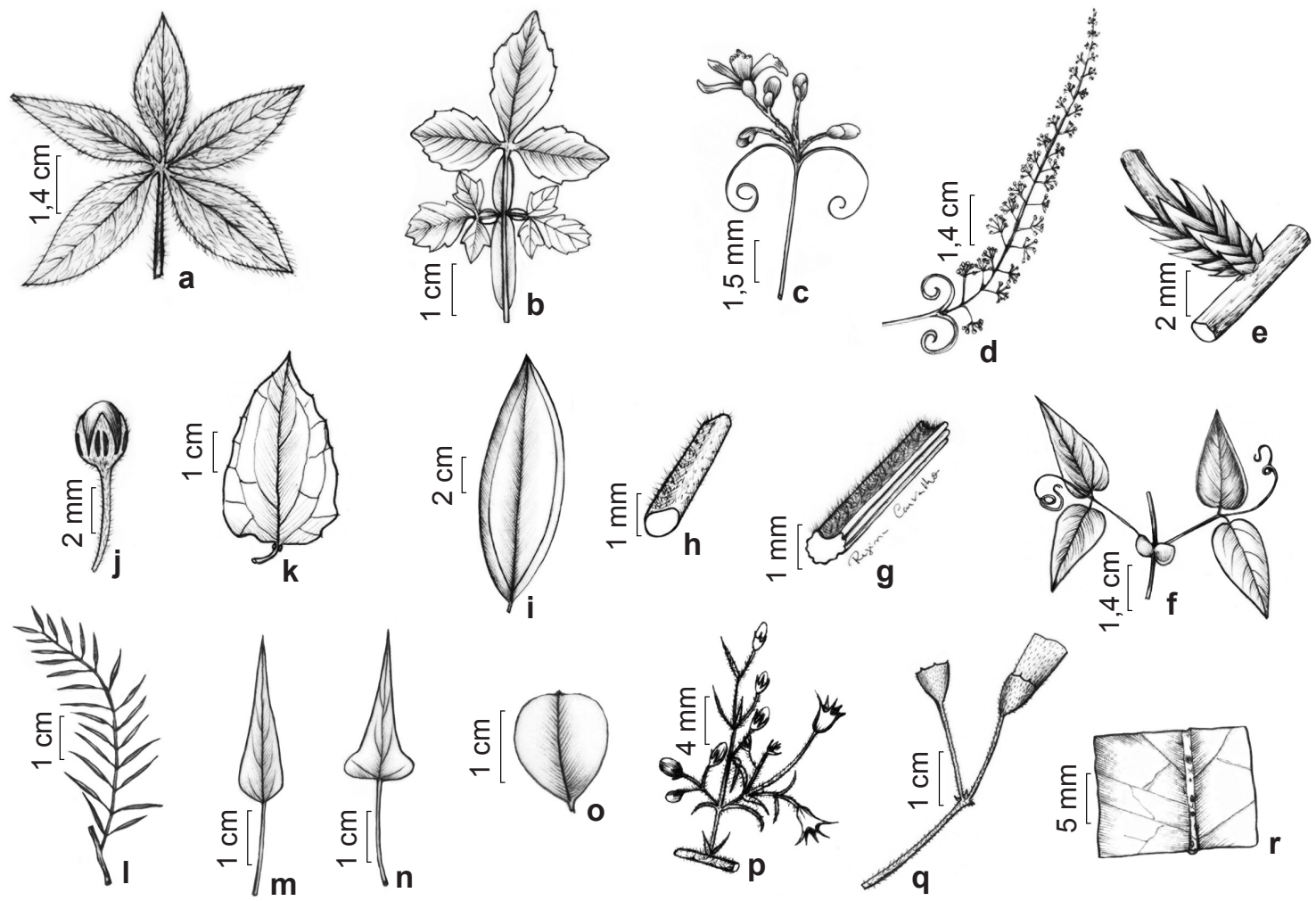

Figura 2 - a. Merremia aegyptia (G.C. Delgado-Junior 426) - folha palmada; b. Serjania marginata (G.C. DelgadoJunior 437) - folíolo com raque alada; c. Cardiospermum corindum (G.C. Delgado-Junior 462) - inflorescência com 5 ramos secundários; d. Serjania glabrata (G.C. Delgado-Junior 399) - inflorescência com mais de 10 ramos secundários; e. Bignonia ramentacea (G.C. Delgado-Junior 660)- profilos escamiformes; f. Anemopaegma laeve (G.C. Delgado-Junior 401) - profilos orbiculares a ovais; g. Pyrostegia venusta (G.C. Delgado-Junior 402) - pecíolo canaliculado; h. Mansoa paganuccii (G.C. Delgado-Junior 369) - pecíolo cilíndrico; i. Strychnos gardneri (G.C. Delgado-Junior 413) - folha trinérvea; j-k. Stigmaphyllon auriculatum (G.C. Delgado-Junior 658) - j. cálice com elaióforos; k. par de glândula no pecíolo; 1. Ditassa capillaris (G.C. Delgado-Junior 472) - folhas lineares; m-n. Ditassa hastata (G.C. Delgado-Junior 588) - m. folhas triangulares; n. folhas hastadas. o. Ditassa rotundifolia (G.C. Delgado-Junior 419) - folhas orbiculares; p. Cuspidaria aff. lateriflora (G.C. Delgado-Junior 659) - inflorescência com brácteas lineares e lacínios longos; q. Fridericia dichotoma (G.C. Delgado-Junior 595) - inflorescência com um par de brácteas triangulares e lacínios do cálice curtos; r. Mandevilla scabra (G.C. Delgado-Junior 498) - coléteres ao longo da nervura principal na face abaxial. Figure 2 - a. Merremia aegyptia (G.C. Delgado-Junior 426) - palmate leaf; b. Serjania marginata (G.C. Delgado-Junior 437) - leaflet rachis alate; c. Cardiospermum corindum (G.C. Delgado-Junior 462) - inflorescence with 5 secondary branches; d. Serjania glabrata (G.C. Delgado-Junior 399) - inflorescence with more than 10 secondary branches; e. Bignonia ramentacea (G.C. Delgado-Junior 660) - prophyll escamiform; f. Anemopaegma laeve (G.C. Delgado-Junior 401) - prophyll orbicular to ovate; g. Pyrostegia venusta (G.C. Delgado-Junior 402) - petiole canaliculate; h. Mansoa paganuccii (G.C. Delgado-Junior 369) - petiole cylindrical; i. Strychnos gardneri (G.C. DelgadoJunior 413) - leaf trinerve; j-k. Stigmaphyllon auriculatum (G.C. Delgado-Junior 658) - j. calyx with elaiophores; k. pair of glands on petiole; 1. Ditassa capillaris (G.C. Delgado-Junior 472) - linear leaves; m-n. Ditassa hastata (G.C. Delgado-Junior 588) - m. triangular leaf; $\mathrm{n}$. hastate leaf; o. Ditassa rotundifolia (G.C. Delgado-Junior 419) - orbicular leaf; p. Cuspidaria aff. lateriflora (G.C. Delgado-Junior 659) inflorescence with linear bract and calyx with long lacinia; q. Fridericia dichotoma (G.C. Delgado-Junior 595) - inflorescence with triangular bract and calyx with short lacinia; r. Mandevilla scabra (G.C. Delgado-Junior 498) - colleter distributed along the midrib on abaxial face. 
com folhas orbiculares a ovais, glabras, ápice retuso a obtuso, comprimento igual ou inferior a $2 \mathrm{~cm}$ e pela flor com corola alva com manchas roxas. Floração nas duas estações e frutificação não observada.

Material selecionado: Buíque, Serra de Jerusalém, 9.VIII.2012, fl., G.C. Delgado-Junior et al 419 (UFP).

8. Mandevilla catimbauensis Souza-Silva, Rapini \& Morales, Edinburgh J. Bot. 67(1): 2-4, f. 1. 2010 .

É reconhecida no PARNA Catimbau pelos ramos glabrescentes a glabros, folhas elípticas, glabras, ápice agudo, base cuneada, coléteres na base da nervura principal da face adaxial, corola hipocrateriforme, roxa com fauce amarela, fruto com comprimento igual ou inferior a $12 \mathrm{~cm} \mathrm{e}$ sementes lineares, sem alas laterais e com tricomas longos no ápice. Floração nas duas estações e frutificação na estação seca.

Material selecionado: Buíque, Serrinha, 3.VII.2013, fl., G.C. Delgado-Junior et al. 666 (UFP); Serra de Jerusalém, 09.X.2012, fr., Delgado Junior et al. 488 (UFP).

9. Mandevilla scabra (Hoffmanns. ex Roem. \& Schult.) K.Schum., in Engler \& Prantl, Nat. Pflanzenfam. 4(2): 171. $1895 . \quad$ Fig. 2r

É reconhecida no PARNA Catimbau pelos ramos pubescentes a glabrescentes, folhas elípticas com face adaxial glabrescente a pubescente, abaxial vilosa, ápice agudo, base cordada, coléteres na base do pecíolo e ao longo da nervura principal da face abaxial. A flor apresenta corola amarela com fauce alaranjada a avermelhada. Floração e frutificação nas duas estações.

Material selecionado: Buíque, Quixel, 9.X.2012, fl., G.C. Delgado-Junior et al. 498 (UFP); Estrada BuíqueCatimbau, 19.VI.1994, fl. e fr., A. Miranda et al. 1749 (HST, PEUFR).

10. Marsdenia hilariana E.Fourn., in Mart. \& Eichler, Fl. bras. 6(4): 322. 1885.

Distingue-se das demais trepadeiras do PARNA Catimbau pelos ramos glabros, folhas elípticas, glabras, margem não ciliada, ápice acuminado a agudo, mucronado, base cuneada, inflorescência glomeriforme, flores com corola urceolada, amarelo-esverdeada com máculas vináceas, polínias eretas e pelo fruto folículo. Frutificação na estação chuvosa e floração não observada.

Material examinado: Buíque, Fazenda de Giovanni, 08.V.2013, fr., G.C. Delgado-Junior et al. 651 (UFP).
11. Matelea maritima (Jacq.) Woodson., Ann. Missouri Bot. Gard. 28: 222. 1941 Fig. 3b

Diferencia-se das espécies do PARNA Catimbau pelos ramos pubescentes, folhas com largura inferior a $3 \mathrm{~cm}$, lanceoladas a ovais, face adaxial pubescente, abaxial vilosa, ápice acuminado, base cordada a truncada. A corola varia de castanha a vinácea e os frutos possuem a superfície tuberculada. Floração nas duas estações e frutificação na estação seca.

Material selecionado: Buíque, Fazenda de Giovanni, 3.VII.2013, fl., G.C. Delgado Junior et al. 686 (UFP); Estrada para Vila do Catimbau, 1.IX.2013, fr., G.C. Delgado Junior et al. 720 (UFP).

12. Schubertia multiflora Mart., Nov. Gen. Sp. Pl. 1: 56, t. 33.1824.

Pode ser reconhecida no PARNA Catimbau pelos ramos hirsutos, folhas com largura superior a $4 \mathrm{~cm}$, obovais a ovais, hirsutas, ápice acuminado, base cordada a truncada, flores pediceladas, corola hipocrateriforme alva, ca. 2,5 cm compr. e fruto com epicarpo liso. Floração e frutificação na estação seca.

Material examinado: Buíque, Estrada para Vila do Catimbau, 1.IX.2013, fl. e fr., G.C. Delgado-Junior et al. 719 (UFP).

13. Skytanthus hancorniifolius (A.DC.) Miers, Apocyn. S. Am. 109. 1878.

Distingue-se das espécies de trepadeiras do PARNA Catimbau por ser inteiramente glabra com coléteres no pecíolo, folhas elípticas a oblongas, ápice agudo, base cuneada, flor hipocrateriforme com corola amarela, fruto com comprimento superior a $15 \mathrm{~cm}$ e sementes oblongo-compressas, com duas alas laterais, sem tricomas. Frutificação e floração nas duas estações.

Material selecionado: Buíque, Trilha da Caverna, 5.XII.2012, fl. e fr., G.C. Delgado-Junior et al. 552 (UFP).

14. Temnadenia violacea (Vell.) Miers, Apocyn. S. Amer. 208. 1878.

Diferencia-se das espécies de trepadeiras do PARNA Catimbau pela presença de látex, folhas elípticas a ovais, pubescentes a vilosas, ápice agudo e mucronado e base obtusa. Possuem inflorescência umbeliforme, corola infundibuliforme violácea com fauce esverdeada e fruto folículo. Floração e frutificação nas duas estações.

Material selecionado: Buíque, Serra de Jerusalém, 7.VII.2012, fr., G.C. Delgado-Junior et al. 382 (UFP); Estrada Buíque-Catimbau, 18.VII.1994 fl. e fr., $A$. Miranda et al. 1751 (HST, IPA, PEUFR). 

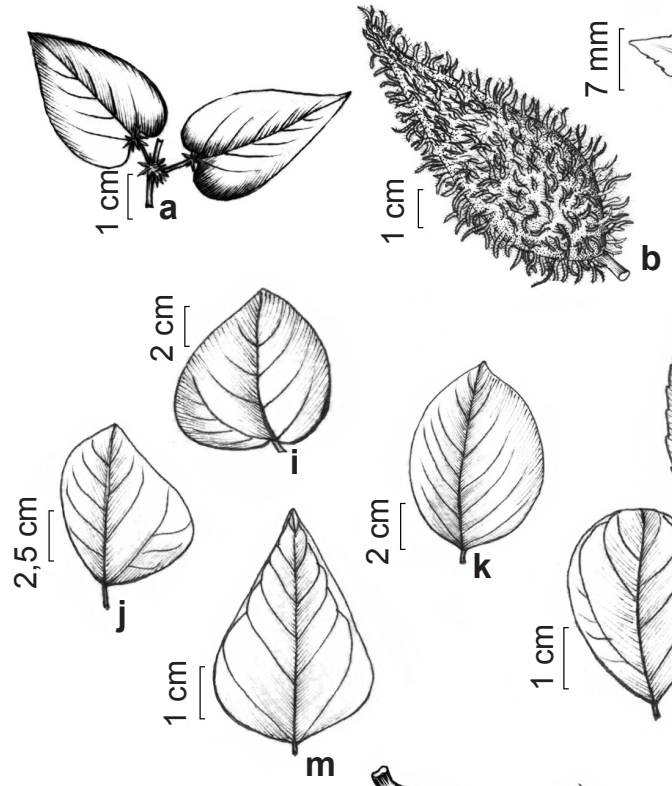

\section{b}
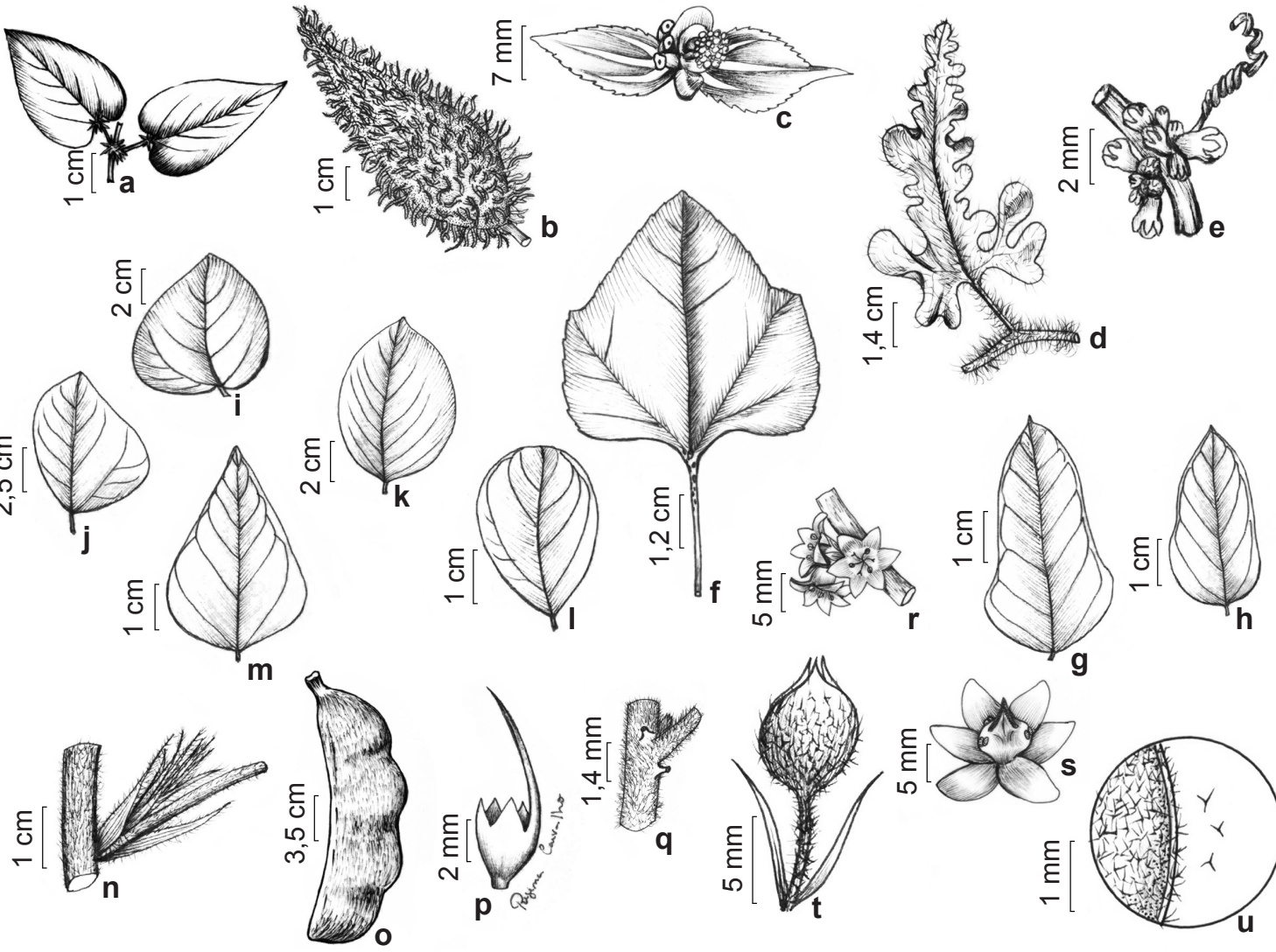

Figura 3 - a. Blepharodon manicatum (A. Miranda 1819) - coléteres nos nós e pecíolos; b. Matelea maritima (G.C. Delgado-Junior 720) - frutos tuberculados; c. Dalechampia schenckiana (G.C. Delgado-Junior 436) - pseudanto; d. Citrullus lanatus (G.C. Delgado-Junior 667) - folha com mais 10 lobos; e. Apodanthera congestiflora (G.C. DelgadoJunior 630) - inflorescência com flores sésseis; f. Cayaponia tayuya (A. Miranda 2743) - base foliar decurrente com glândulas; g. Macroptilium bracteatum (G.C. Delgado-Junior 694) - folíolo deltoide; h. Ancistrotropis peduncularis (G.C. Delgado-Junior 699) - folíolo oval a lanceolado; i-j. Macroptilium martii (G.C. Delgado-Junior 670) - i. folíolo suborbicular a oval; j. folíolo assimétrico; k. Periandra coccinea (G.C. Delgado-Junior 603) - folíolo oval a elíptico; 1. Dioclea grandiflora (G.C. Delgado-Junior 322) - folíolo oboval a suborbicular; m. Canavalia brasiliensis (G.C. Delgado-Junior 693) - folíolo oval; n. Macroptilium bracteatum (G.C. Delgado-Junior 694) - fascículo de brácteas na base do pedúnculo; o. Dioclea grandiflora (G.C. Delgado-Junior 322) - fruto com margem arqueada; p. Centrosema arenarium (G.C. Delgado-Junior 435) - cálice com pelo menos um dente maior que o tubo; q. Securidaca diversifolia (G.C. Delgado-Junior 492) - glândulas na inserção do pecíolo no ramo; r. Dioscorea leptostachya (A. Miranda 1724) - flores masculinas sésseis; s. Dioscorea subhastata (G.C. Delgado-Junior 702) - flor masculina com três estames soldados à coluna carnosa; t. Jacquemontia mucronifera (G.C. Delgado-Junior 463) - cálice e bractéolas; u. Jacquemontia evolvuloides (G.C. Delgado-Junior 468) - tricomas 3-armados.

Figure 3 - a. Blepharodon manicatum (A. Miranda 1819) - colleter on nodes and petioles; b. Matelea maritima (G.C. Delgado-Junior 720) - tuberculate fruit; c. Dalechampia schenckiana (G.C. Delado-Junior 436) - pseudanthium; d. Citrullus lanatus (G.C. DelgadoJunior 667) - leaf with more than 10 lobes; e. Apodanthera congestiflora (G.C. Delgado-Junior 630) - sessile inflorescence; f. Cayaponia tayuya (A. Miranda 2743) - decurrent leaf base with glands; g. Macroptilium bracteatum (G.C. Delgado-Junior 694) - deltoid leaflet; h. Ancistrotropis peduncularis (G.C. Delgado-Junior 699) - ovate to lanceolate leaflet; i-j. Macroptilium martii (G.C. Delgado-Junior 670) - i. suborbicular to ovate leaflet; j. asymmetric leaflet; k. Periandra coccinea (G.C. Delgado-Junior 603) - ovate to elliptic leaflet; 1. Dioclea grandiflora (G.C. Delgado-Junior 322) - obovate to suborbicular leaflet; m. Canavalia brasiliensis (G.C. Delgado-Junior 693) - ovate leaflet; n. Macroptilium bracteatum (G.C. Delgado-Junior 694) - fascicle of bracts on peduncle; o. Dioclea grandiflora (G.C. Delgado-Junior 322) - fruit with arched margin; p. Centrosema arenarium (G.C. Delgado-Junior 435) - calyx with one tooth longer than tube; q. Securidaca diversifolia (G.C. Delgado-Junior 492) - glands next to petiole; r. Dioscorea leptostachya (A. Miranda 1724 ) - sessile male flower; s. Dioscorea subhastata (G.C. Delgado-Junior 702) - male flower with three stamens fused into a fleshy column; t. Jacquemontia mucronifera (G.C. Delgado-Junior 463) - calyx and bracteoles; u. Jacquemontia evolvuloides (G.C. DelgadoJunior 468) - trichomes 3-armed. 
Bignoniaceae Juss.

15. Anemopaegma laeve DC., Prodr. 9: 189. 1845.

Fig. $2 f$

Diferencia das demais trepadeiras do PARNA Catimbau pelos ramos glabros, folhas 2-folioladas com folíolos ovais a elípticos, pilosos a glabros, margem revoluta, profilos orbiculares a ovais, conspícuos, corola creme a amarelada e pelo fruto elipsoide, achatado dorsiventralmente. Floração nas duas estações e frutificação na estação seca. Material selecionado: Buíque, Brocoto, 8.VIII.2012, fl., G.C. Delgado-Junior et al. 401 (UFP); Chapadão, 30.V.2012, fr., G.C. Delgado-Junior et al. 326 (UFP).

16. Bignonia ramentacea (Mart. ex DC.) L.G. Lohmann, Ann. Missouri Bot. Gard. 99(3): 422. 2014.

Fig. 2e

É reconhecida no PARNA Catimbau pelos ramos glabros, lenticelados, folhas 2-folioladas, raro simples, folíolos elípticos a ovais, glabros, profilos escamiformes, conspícuos, dispostos em roseta e corola variando de rosa a lilás com fauce branca. Floração na estação seca e frutificação não observada.

Material selecionado: Buíque, Alcobaça, 09.V.2013, fl., G.C. Delgado-Junior et al. 660 (UFP).

\section{Cuspidaria aff. lateriflora.}

Fig. $2 p$

É reconhecida no Catimbau pelos ramos glabros, lenticelados, folhas 3 -folioladas com folíolos ovais a lanceolados, pubescentes, profilos triangulares. Apresentam vários pares de brácteas lineares, conspícuas ao longo da inflorescência, corola variando de lilás a rosa e com lacínios do cálice longos, superiores a 2,5 $\mathrm{mm}$ de comprimento. Floração nas duas estações e frutificação não observada.

Material selecionado: Búque, Alcobaça, 9.V.2013, fl., G.C. Delgado-Junior et al. 659 (UFP).

18. Fridericia dichotoma (Jacq.) L.G.Lohmann, Ann. Missouri Bot. Gard. 99(3): 436-437. 2014.

Fig. $2 q$

É reconhecida no PARNA Catimbau pelos ramos glabros, lenticelados, folhas 3-folioladas com folíolos oblongos a oblanceolados, velutinos, ápice cuspidado, base arredondada. Inflorescência em racemo com um par de brácteas triangulares, caducas, corola lilás com fauce branca e lacínios do cálice curtos, igual ou inferior a $1 \mathrm{~mm}$ de comprimento. Floração nas duas estações e frutificação na estação seca.

Material selecionado: Buíque, Fazenda Brejo de São José, 16.I.2013, fl. e fr., G.C. Delgado-Junior et al. 595 (UFP).
19. Fridericia limae (A.H.Gentry) L.G.Lohmann, Ann. Missouri Bot. Gard. 99(3): 440. 2014.

Distingue-se das demais trepadeiras do PARNA Catimbau pelas folhas 3-folioladas com folíolos elípticos a ovais, glabros, ápice agudo, raro mucronado, base arredondada, base do pecíolo glabra e corola alva. Floração nas duas estações e a frutificação na estação chuvosa.

Material selecionado: Buíque, Caminho para Concha, 7.V.2013, bt., fr., G.C. Delgado-Junior et al. 639 (UFP).

20. Fridericia parviflora (Mart. ex DC.) L.G. Lohmann, Ann. Missouri Bot. Gard. 99(3): 441, 2014.

É facilmente reconhecida no PARNA Catimbau pelas folhas 3-folioladas com folíolos oblongos, elípticos a ovais, face adaxial glabrescente a glabra, abaxial pubescente, ápice arredondado ou agudo mucronado, base cuneada, margem denteada e corola em tons lilás e de rosa a salmão. Floração nas duas estações e frutificação na estação seca.

Material selecionado: Buíque, Trilha das Torres, 9.VIII.2012, fl. e fr., G.C. Delgado-Junior et al. 409 (UFP).

21. Mansoa paganuccii M.M.Silva-Castro, Phytotaxa 258(1): 59-61. 2016.

Fig. $2 \mathrm{~h}$

É reconhecida no PARNA Catimbau pelos ramos glabros, gavinhas trifurcadas no ápice, folhas 3 -folioladas com folíolos elípticos a lanceolados, glabros, ápice agudo, base subcordada a arredonda, pecíolo cilíndrico, pubescente e corola roxa a magenta. Floração nas duas estações e frutificação não observada.

Material selecionado: Buíque, Sítio Serrinha, 1.VI.2012, bt., fl., G.C. Delgado-Junior et al. 369 (UFP).

22. Pyrostegia venusta Miers, Proc. Roy. Hort. Soc. London 3: 188. 1863.

Fig. $2 g$

É reconhecida no PARNA Catimbau pelos ramos glabros, gavinhas trífidas, folhas 2(-3)-folioladas com folíolos ovais, glabros, ápice agudo a acuminado, base arredondada a subcordada, pecíolo canaliculado, piloso apenas ao longo do sulco, profilos filiformes e corola alaranjada. Floração na estação seca e a frutificação nas duas estações.

Material selecionado: Buíque, Breu, 8.VII.2012, fl. e fr., G.C. Delgado-Junior et al. 402 (UFP).

Combretaceae R.BR.

23. Combretum hilarianum D.Dietr, Syn. Pl. 2: 1303. 1840.

Difere-se das demais espécies de trepadeiras do PARNACatimbau pelos ramos vilosos, estípulas ausentes, folhas elípticas a lanceoladas, face adaxial 
vilosa a glabrescente, abaxial vilosa, ápice agudo, base obtusa a subcordada, corola esverdeada e betulídio 4-alados. Floração na estação chuvosa e frutificação na estação seca.

Material selecionado: Buíque, Sitio Juá, 1.IX.2013, fr., G.C. Delgado-Junior et al. 716 (UFP); Trilha para os homens sem cabeça, 3.VII.2013, fl. e fr., G.C. DelgadoJunior et al. 676.

Convolvulaceae Juss.

24. Daustinia montana (Moric.) Buril \& A.R. Simões, Phytotaxa 197(1): 60. 2015.

Distingue-se das demais trepadeiras do PARNA Catimbau pelos ramos lanosos, folhas com comprimento superior a $3,5 \mathrm{~cm}$, ovais, lanosas, ápice agudo, mucronado, base truncada a ligeiramente cordada, inflorescência em cimeira capituliforme e corola amarela. Floração na estação seca e frutificação não observada.

Material selecionado: Buíque, Estrada para Vila do Catimbau, 1.IX.2013, fl., G.C. Delgado-Junior et al. 712 (UFP).

25. Ipomoea bahiensis Willd. ex Roem. \& Schult., Syst. Veg., ed. 15, 4: 789. 1819.

É reconhecida no PARNA Catimbau pelas folhas sagitadas a cordadas, pubescentes a glabras, ápice agudo e mucronado, base sagitada a cordada, sépalas com rostro subapical menor ou igual a $1 \mathrm{~cm}$ de comprimento e corola roxa. Floração e frutificação na estação seca.

Material selecionado: Buíque, Trilha para Vila do Catimbau, 7.V.2013, fl., G.C. Delgado-Junior et al. 623 (UFP); Vale do Catimbau, 29.IX.2004, fl. e fr., R.A. Pick 56 (UFP).

26. Ipomoea brasiliana Meisn., in Mart., Fl. bras. 7: 261.1869.

Difere-se das demais trepadeiras do PARNA Catimbau pelos ramos vilosos, folhas cordadas, face adaxial vilosa a glabrescente, abaxial vilosa, ápice agudo, base cordada e sépalas externas levemente maiores que as internas, glabrescentes a glabras. Floração nas duas estações e frutificação na estação seca.

Material selecionado: Buíque, Serra de Jerusalém, 12.IX.2012, fl., G.C. Delgado-Junior et al.453 (UFP); Fazenda Laranjeira, 9.VI.1995, fr., Figueiredo et al. 109 (PEUFR).

27. Ipomoea grandifolia (Dammer) O'Donell, Arq. Mus. Paranaense 9: 222, f. 6. 1952.

Caracterizada no PARNA Catimbau pelos ramos esparsamente pubescentes, folhas 3-lobadas a inteiras, glabrescentes a glabras, ápice agudo a acuminado e mucronado, base cordada, sépalas membranáceas, as externas, com nervura evidente e ciliadas e corola rosa. Floração na estação seca e frutificação não observada.

Material examinado: Buíque, Alcobaça, VIII.2007, bt., fl., O. Cano et al. 835 (IPA).

28. Ipomoea hederifolia L., Syst. Nat., ed. 10, 2: 925. 1759.

Diferencia-se das demais trepadeiras do PARNA Catimbau pelos ramos glabrescentes a glabros, folhas ovais, glabras, ápice agudo, base profundamente cordada, sépalas com arista superior a $2,5 \mathrm{~cm}$ de comprimento e corola hipocrateriforme vermelha com estames exsertos. Floração na estação chuvosa e frutificação não observada.

Material examinado: Buíque, Vale do Catimbau, 17.VI.2008, fl., R. Pereira et al. 2833 (IPA).

29. Ipomoea longeramosa Choisy, In A.P. de Candolle, Prodr. 9: 384. 1845.

Difere-se das demais trepadeiras do PARNA Catimbau pelos ramos hirsutos, folhas 5-lobadas, glabrescentes, lobos ovais a elípticos, ápice agudo a arredondado, mucronado, base assimétrica, sépalas não ciliadas e corola amarela com fauce vinácea. Floração e frutificação na estação seca.

Material selecionado: Buíque, Estrada para o Alcobaça, 31.VIII.2013, fl. e fr., G.C. Delgado-Junior et al. 695 (UFP).

30. Ipomoea marcellia Meisn., in Mart., Fl. bras. 7: 257.1869.

Difere-se das demais espécies de trepadeiras do PARNA Catimbau pelos ramos vilosos, folhas cordadas, vilosas, ápice agudo, base cordada, nervuras proeminentes na face abaxial e corola branco-amarelada com estames exsertos. Floração e frutificação na estação chuvosa .

Material selecionado: Buíque, Igrejinha, 2.IV.2012, fl., G.C. Delgado-Junior et al. 297 (UFP); Vale do Catimbau, VI.2007, bt., fr., O. Cano 795 (IPA).

31. Ipomoea nil (L.) Roth, Catal. Bot. 1: 36. 1797.

É reconhecida no PARNA Catimbau pelos ramos hirsutos, folhas ovais, esparsamente hirsutas, ápice caudado, base cordada, sépalas iguais entre si, densamente hirsuta na base e corola rosa. Floração nas duas estações e frutificação na estação seca. Material selecionado: Buíque, Estrada para o Alcobaça, 31.VIII.2012, fl., G.C. Delgado-Junior et al. 690 (UFP); Caiana, 6.VIII.2006, fl. e fr., M.T. Vital et al. 41 (UFP). 
32. Ipomoea pintoi O'Donell, Lilloa 26: 380. 1953.

É reconhecida no PARNA Catimbau por ser inteiramente glabra com folhas elípticas a oblanceoladas, ápice acuminado, base cuneada, nectários no pecíolo e pedicelo e sépalas iguais entre si e corola rosa. Floração e frutificação nas duas estações.

Material selecionado: Buíque, Igrejinha, 8.VIII.2012, fr., G.C. Delgado-Junior et al. 404 (UFP); Serra Branca, 8.VII.2012, fl., G.C. Delgado-Junior et al. 391 (UFP).

33. Ipomoea piurensis O’Donell, Lilloa 26: 3811953.

Diferencia-se das demais trepadeiras do PARNA Catimbau pelas folhas cordadas, glabrescentes a glabras, ápice agudo e mucronado, base cordada, pedicelo com comprimento igual ou inferior a $5 \mathrm{~mm}$ e sépalas externas rugosas, glabras. Floração na estação seca, frutificação não observada.

Material selecionado: Buíque, Estrada para o Alcobaça, 31. VIII.2013, fl., G.C. Delgado-Junior et al. 691 (UFP).

34. Ipomoea rosea Choisy, in A.P. de Candolle, Prodr. 9: 384. 1845.

É reconhecida no PARNA Catimbau por ser a única trepadeira herbácea inteiramente glabra, 3-foliolada com folíolos elípticos, ápice agudo, mucronado, base cuneada, sépalas com rostro subapical e corola rosa. Floração e frutificação na estação chuvosa.

Material selecionado: Buíque, Igrejinha, 6.V.2013, fl., G.C. Delgado-Junior et al. 619 (UFP).

35. Ipomoea setosa Ker Gawl., Bot. Reg. 4:335. 1818.

Distingue-se das demais trepadeiras do PARNA Catimbau pelos tricomas híspidos e alongados nos ramos, folhas ovais, lobadas, margem denteada, glabras, sépalas glabras, mucronadas e corola rosa. Floração na estação chuvosa, frutificação não observada.

Material examinado: Búque, Sítio Serrote Preto, 19. VI.2008, bt., fl., R. Pereira 2702 (IPA).

36. Ipomoea subalata Hassl., Repert. Spec. Nov. Regni Veg. 9: 157. 1911.

É reconhecida no PARNA Catimbau pelas folhas cordadas com face adaxial glabra e face abaxial pubescente, pedicelo com comprimento igual ou superior a $1 \mathrm{~cm}$, sépalas externas coriáceas com tricomas esparsos e sépalas internas com margem escariosa. Floração nas duas estações e frutificação não observada

Material selecionado: Buíque, Sítio Breu, 1.VI.2012, fl., G.C. Delgado-Junior et al. 364 (UFP).
37. Ipomoea subincana (Choisy) Meisn., in Mart., Fl. bras. 7: 259. 1869

Caracterizada no PARNA Catimbau pelos ramos vilosos, folhas cordadas, face adaxial densamente vilosa, ápice agudo e mucronado, base cordada, sépalas externas ovais a rotundas vilosas, sendo as internas um pouco maiores que as externas, glabrescentes a glabra, mesopétala glabra e fruto deiscente. Floração e frutificação nas duas estações.

Material selecionado: Buíque, Serra Branca, 31.V.2012, fl. e fr., G.C. Delgado-Junior et al. 329 (UFP).

38. Jacquemontia chrysanthera Buril, Brittonia 63(4): 436. 2011.

É reconhecida no PARNA Catimbau pelas folhas ovais, vilosas com tricomas estrelados com 5(-7) braços armados e corola azul com anteras amareladas. Floração nas duas estações e frutificação na estação chuvosa.

Material selecionado: Buíque, Trilha para Caverna, 12.IX.2012, fl., G.C. Delgado-Junior et al. 439 (UFP); Serra de Jerusalém, 7.VII.2012, fr., G.C. Delgado-Junior \& S.O. Santos 372 (UFP).

39. Jacquemontia corymbulosa Benth., Bot. Voy. Sulphur 137. 1844.

Distingue-se das demais trepadeiras do PARNA Catimbau pelas folhas cordadas a ovais, vilosas, bractéolas lineares, sépalas desiguais entre si, as externas elípticas a lanceoladas, pubescentes e corola completamente azul. Floração e frutificação nas duas estações.

Material selecionado: Buíque, Casa de Farinha, 9.VIII.2012, fl. e fr., G.C. Delgado-Junior et al. 411 (UFP).

40. Jacquemontia evolvuloides (Moric.) Meisn, in Mart., Fl. bras. 7: 307. $1869 . \quad$ Fig. 3u

Diferencia-se das demais trepadeiras do PARNA Catimbau pelos ramos com tricomas glandulares, folhas cordadas, pubescentes com tricomas glandulares e estrelados e corola azul. Floração e frutificação na estação seca.

Material selecionado: Buíque, Trilha para Vila do Catimbau, 8.XI.2012, fl., G.C. Delgado-Junior et al. 468 (UFP); Serra de Jerusalém, 19.X.1994, fl. e fr., M.F. Sales 431 (PEUFR).

41. Jacquemontia mucronifera (Choisy) Hallier f., Bot. Jahrb. Syst. 16: 543 (1893). Fig. 3t

É reconhecida no PARNA Catimbau pelos ramos densamente pubescentes, folhas ovais, vilosas, sépalas externas rômbicas a ovais, pubescentes, bractéolas lineares e pedicelo com 
comprimento igual ou inferior a $2 \mathrm{~mm}$. Floração nas duas estações e frutificação na estação seca.

Material selecionado: Buíque, Trilha do Camelo 13.IX.2012, fl., G.C. Delgado Junior et al. 463 (UFP); Serra de Jerusalém, 12.IX.2012, fl. e fr., G.C. Delgado- Junior 448 (UFP).

42. Jacquemontia nodiflora (Desr.) G. Don., Gen. Hist. 4: 283.1838

Reconhecida no PARNACatimbau pelas folhas ovais, velutinas, sépalas subiguais entre si, rotundas, pubescentes a glabrescentes na base, bractéolas com comprimento igual ou inferior a $1 \mathrm{~mm}$ e corola branca com fauce vinácea. Floração nas duas estações e frutificação na estação seca.

Material selecionado: Buíque, Quixel, 9.VIII.2012, fl., G.C. Delgado-Junior et al. 424 (UFP); 9.X.2012, fr., G.C. Delgado-Junior 487 (UFP).

43. Jacquemontia pentanthos (Jacq) G.Don, Gen. Hist. 4: 283. 1838.

Diferencia-se das demais espécies trepadeiras do PARNA Catimbau pelos ramos velutinos a glabrescentes, folhas ovais, pubescentes, bractéolas lanceoladas ou oblanceoladas e sépalas desiguais entre si. Floração na estação chuvosa e frutificação não observada.

Material examinado: Buíque, Riachão, 25.VI.2010, fl., $M$. Oliveira et al. 4973 (HVASF).

44. Merremia aegyptia (L.) Urb., Symb. Antill. 4: 505. 1910.

Fig. 2a

Distingue-se das demais trepadeiras do PARNA Catimbau pelos ramos, pecíolo, pedúnculo e sépalas hirsutas, folhas 5-folioladas (palmadas) com folíolos elípticos e corola branca. Floração nas duas estações e frutificação não observada.

Material selecionado: Buíque, Trilha para Vila do Catimbau, 12.IX.2012, fl., G.C. Delgado-Junior et al. 426 (UFP).

45. Merremia cissoides (Lam.) Hallier f., Bot. Jahrb. Syst. 16: 552. 1893.

Reconhecida no PARNA Catimbau pelos tricomas glandulares nos ramos, folhas 5-(6)-folioladas (palmadas) com tricomas glandulares restritos à margem; margem denteada e corola branca. Floração na estação chuvosa e frutificação não observada.

Material selecionado: Buíque, Fazenda Laranjeiras, 20.V.1995, fl., K. Andrade et al. 55 (PEUFR).

46. Turbina cordata (Choisy) Austin \& Staples, J. Arnold Arbor. 64: 488. 1983.

Difere-se das demais trepadeiras do PARNA Catimbau pela face adaxial glabrescente com tricomas restritos às nervuras, face abaxial densamente vilosa, sépalas externas e internas pubescentes, mesopétala vilosa e frutos indeiscentes. Floração e frutificação na estação seca.

Material examinado: Buíque, Alcobaça, 10.XII.2012, bt., G.C. Delgado-Junior et al. 503 (UFP); Trilha das Torres, 18.XI.2008, fl., R. Pereira 2844 (IPA).

Cucurbitaceae Juss.

47. Apodanthera congestiflora Cogn., Pflanzenr. IV 275 I (Heft 66): 66. 1916.

Fig. 3e

Distingue-se das demais espécies de trepadeiras do PARNA Catimbau pelas folhas variando de simples a 3-folioladas, gavinhas subopostas às folhas, ramos pilosos a glabros e pelas flores esverdeadas inconspícuas menores que $2 \mathrm{~mm}$ de comprimento reunidas em um fascículo nodal séssil a subséssil. Floração e frutificação nas duas estações.

Material selecionado: Buíque, Caiana, 7.V.2013, fl., G.C. Delgado-Junior et al. 630 (UFP); Pedra do Cachorro, 17.I.2013, fr. G.C. Delgado-Junior et al. 615 (UFP).

48. Apodanthera glaziovii Cogn., Bull. Soc. Bot. France 3d: 318. 1909.

Difere-se das demais trepadeiras do PARNA Catimbau pelos ramos pilosos, folhas ovais, inteiras a levemente lobadas, pilosas, ápice agudo ou assimétrico, base cordada flores pistiladas solitárias e flores estaminadas reunidas em racemo e pedúnculo variando de 2 a $4 \mathrm{~cm}$ de comprimento. Floração na estação chuvosa e frutificação não observada.

Material selecionado: Buíque, Canyon, 3.VII.2013, fl., G.C. Delgado-Junior et al. 679 (UFP).

49. Cayaponia martiana Cogn., Monogr. Phan. 3: 777. 1881.

É reconhecida no PARNA Catimbau pelos ramos glabrescentes e pelas folhas 3-5 lobadas com lobos oblongo-lanceolados, pubescentes, margem denticulada, ápice assimétrico, base não decurrente e sem glândulas. Floração e frutificação na estação chuvosa.

Material examinado: Buíque, Catimbau, 19.VI.2008, fl. e fr., R. Pereira et al. 2713 (IPA).

50. Cayaponia tayuya (Vell.) Cogn., in A. DC., Monogra. Phan. 3: 772. 1881 Fig. 3f

Distingue-se das demais trepadeiras do PARNA do Catimbau pelos ramos pubescentes e pelas folhas inteiras a 3-5 lobadas, deltoides a ovais, pubescentes, base decurrente com glândulas. Floração na estação chuvosa e frutificação não observada.

Material examinado: Buíque, Estrada Buíque-Catimbau, 11.VII.1997, bt., fl., A. Miranda et al. 2743 (HST). 
51. Citrullus lanatus (Thunb.) Matsum. \& Nakai, Cat. Sem. Spor. Hort. Bot. Univ. Imp. Tokyo 30: 854. 1916.

Fig. 3d

É reconhecida no PARNA Catimbau pelos ramos densamente lanosos e pelas folhas pinatífidas com mais de 10 lobos, lobos ovais a oblongos ou assimétricos, glabrescentes. Floração e frutificação na estação chuvosa.

Material selecionado: Buíque, Serrinha, 3.VII.2013, fl. e fr., G.C. Delgado-Junior et al. 667 (UFP).

52. Cucumis anguria L., Sp. pl. 2: 1011. 1753.

É caracterizada no PARNA Catimbau pelos ramos esparsamente hirsutos, folhas 3-5-7 lobadas com lobos ovais a obovais, pilosas, ápice arredondado, e inflorescência com até 5 flores. Floração e frutificação na estação chuvosa.

Material examinado: Buíque, Alcobaça, 19.VII. 2008, fl. e fr., R. Pereira et al 2776. (IPA).

53. Momordica charantia L., Sp. pl. 2: 10091010. 1753.

Diferencia-se das demais trepadeiras do PARNA do Catimbau pelos ramos pilosos a glabrescentes, folhas 5-7 palmatipartidas, glabrescentes, ápice dos lobos laterais agudo e mucronado. Floração nas duas estações e a frutificação na estação chuvosa.

Material selecionado: Buíque, Estrada para o Alcobaça, 9.V.2013, fl. e fr., G.C. Delgado-Junior et al. 654 (UFP).

Dioscoreaceae R. BR.

54. Dioscorea cinnamomifolia Hook., Curtis's Bot. Mag. 2: 2825. 1828.

Diferencia-se das demais espécies do PARNA do Catimbau pelas folhas glabras com sinus da base foliar menor que $3 \mathrm{~mm}$ de comprimento, tricomas na inserção do pecíolo no ramo e pelas flores estaminadas com 6 estames livres. Floração e frutificação nas duas estações.

Material selecionado: Buíque, Casa de Farinha, 9.VIII.2012, fl., G.C. Delgado-Junior et al. 416 (UFP); Trilha das Torres, 9.VIII.2002, fr., G.C. Delgado-Junior et al. 408 (UFP).

55. Dioscorea leptostachya Gardn., in Hooker, Lond. J. Bot. 1: 534. 1842.

Fig. 3r

Espécie caracterizada no PARNA Catimbau pelos ramos e folhas glabras, flores estaminadas sésseis em espiga, com 3 estames livres e flores pistiladas com tépalas unguiculadas. Floração e frutificação na estação chuvosa.

Material selecionado: Buíque, Estrada Buíque-Catimbau, 19.VII.1994, fl. e fr., A. Miranda et al. 1724 (PEUFR).
56. Dioscorea piperifolia Humb. \& Bonpl. ex Willd., in Willdenow, Sp. P1. 4: 795. 1805.

Distingue-se das demais espécies do PARNA do Catimbau pelas folhas glabras com sinus da base foliar maior que $1 \mathrm{~cm}$ de comprimento, pontuações verdes (escuras quando herborizadas) na base da face abaxial da folha e pelas flores estaminadas com 6 estames livres. Floração estação chuvosa e frutificação não observada.

Material selecionado: Buíque, Serra de Jerusalém, 3.VII.2013, fl., G.C. Delgado-Junior et al. 681 (UFP).

57. Dioscorea subhastata Vell. Fl. Flum. Icon. 10: tab. 121. 1831; Arch. Mus Nac. Rio de Janeiro 5: 425. 1881.

Fig. 3s

Reconhecida no PARNA do Catimbau por ser inteiramente glabra, apresentar de 7 a 9 nervuras proeminentes na face abaxial das folhas, flores estaminadas com três estames soldados à coluna carnosa, inflorescência pistilada com duas flores por nó e tépalas multinervadas. Floração na estação seca e frutificação não observada.

Material examinado: Buíque, Alcobaça, 31.VIII.2013, f1., G.C. Delgado-Junior et al. 702 (UFP).

Euphorbiaceae Juss.

58. Dalechampia schenckiana Pax \& K.Hoffm., Pflanzenr., IV. 147 XII (Heft 68): 49. 1919.

Fig. 3c

Difere-se das demais trepadeiras do PARNA Catimbau pelos ramos pilosos, folhas lanceoladas a ovais, pilosas a vilosas e pelas inflorescências em pseudanto portando brácteas foliáceas. Floração e frutificação nas duas estações.

Material selecionado: Buíque, Cachoeira, 12.IX.2012, fl. e fr., G.C. Delgado-Junior et al. 436 (UFP).

59. Tragia volubilis L., Sp. pl. 2: 980. 1753.

É reconhecida no PARNA Catimbau pelos tricomas tectores e urticantes nos ramos e folhas; folhas lanceoladas, pilosas a hirsutas e flores esverdeadas sésseis a subsésseis. Floração nas duas estações e frutificação na estação chuvosa. Material selecionado: Buíque, Fazenda Giovanni, 3.VII.2013, fl. e fr., G.C. Delgado-Junior et al. 688 (UFP).

Fabaceae Lindl.

60. Ancistrotropis peduncularis (Kunth) A. Delgado, Amer. J. Bot 98(10): 1704. 2011.

Fig. 3h

É caracterizada no PARNA Catimbau pelos ramos esparsamente pubescentes, folhas 3-folioladas com folíolos assimétricos, deltoides ou ovais a lanceolados, pubescentes a 
glabrescentes, pedúnculo com comprimento igual ou superior a $8 \mathrm{~cm}$, dentes do cálice mais curtos que o tubo; alas lilases e frutos lineares com comprimento igual ou superior a $5 \mathrm{~cm}$. Floração e frutificação na seca.

Material examinado: Buíque, Alcobaça, 31.X.2013, fl. e fr., G.C. Delgado-Junior et al. 699 (UFP).

61. Canavalia brasiliensis Mart. ex Benth., Comm. Legum. Gen. 71. $1837 . \quad$ Fig. 3m

Difere-se das demais trepadeiras do PARNA Catimbau pelos ramos pilosos a glabrescentes, folhas 3-folioladas com largura superior a 4 $\mathrm{cm}$, folíolos ovais, elípticos a assimétricos, face adaxial glabrescente a glabra, abaxial pubescente, ápice agudo, base cuneada, cálice com 4 dentes, piloso e fruto pubescente com margem plana. Floração e frutificação na estação seca.

Material selecionado: Buíque, Estrada para o Alcobaça, 31.VIII.2012, fl. e fr., G.C. Delgado-Junior et al. 693 (UFP).

62. Centrosema arenarium Benth., Comm. Legum. Gen. 55. $1837 . \quad$ Fig. 3p

Pode ser diferenciada no PARNA Catimbau pelos ramos pubescentes, folhas 3-folioladas com folíolos elípticos, lanceolados ou ovais a oblongos, glabros a pubescentes e ao menos um dente do cálice maior que o comprimento do tubo. Floração e frutificação nas duas estações.

Material selecionado: Buíque, Cachoeira, 12.IX.2012, fr., G.C. Delgado-Junior et al. 435 (UFP); IX.2012, fl., G.C. Delgado-Junior et al. 438 (UFP).

63. Centrosema brasilianum (L.) Benth., Comm. Legum. Gen. 54. 1837.

É reconhecida no PARNA Catimbau pelas folhas 3-folioladas com folíolos elípticos a oblongos, glabrescentes a pubérulos e todos os dentes do cálice menores que o comprimento do tubo, bractéola com comprimento superior a 10 $\mathrm{mm}$, flor solitária e fruto glabro. Floração nas duas estações e frutificação na estação seca.

Material selecionado: Buíque, Estrada para Igrejinha, 8.VIII.2012, fl. e fr., G.C. Delgado-Junior et al. 407 (UFP).

64. Centrosema coriaceum Benth., Comm. Legum. Gen. 54. 1837.

Diferente das demais espécies do PARNA Catimbau por ser completamente glabra com folhas 3-folioladas com folíolos coriáceos, elípticos a oblongos, ápice emarginado, mucronado e base arredondada. Floração nas duas estações e frutificação na estação seca.
Material selecionado: Buíque, Chapadão, 13.IX.2012, fl., G.C. Delgado-Junior et al. 460 (UFP); Serra de Jerusalém, 9.X.2012, fr., G.C. Delgado-Junior et al. 487 (UFP).

65. Centrosema pubescens Benth., Comm. Legum. Gen. 54. 1837.

É diferenciada das demais trepadeiras do PARNA Catimbau por apresentar ramos pilosos, folhas 3-folioladas com folíolos elípticos, lanceolados a ovais, pilosos a glabrescentes, ápice agudo, base arredondada, bractéolas com comprimento inferior a $10 \mathrm{~mm}$, inflorescência com 2 ou mais flores, dentes do cálice menores que o comprimento do tubo e fruto pubescente. Floração na estação seca e frutificação não observada.

Material selecionado: Buíque, Sítio Serra Branca, 21.X.2006, fl., A. Rocha et al. 1562 (IPA).

66. Chaetocalyx scandens var. pubescens (DC.) Rudd, Contr. U.S. Natl. Herb. 32(3): 236. 1958.

É reconhecida no PARNA Catimbau pelos ramos pubescentes, estípulas presentes, folhas pinadas e imparipinadas, 5-folioladas com folíolos elípticos a ovais, ápice arredondado a agudo, mucronado, base arredondada a cuneada, corola amarela e fruto lomentoso. Floração nas duas estações e frutificação não observada.

Material selecionado: Buíque, Serra de Jerusalém, 9.X.2012, fl., G.C. Delgado-Junior et al. 493 (UFP).

67. Dioclea grandiflora Mart. ex Benth., Comm. Legum. Gen. 68-69. 1837.

Fig. 31,o

Difere-se das demais espécies de trepadeiras do PARNA Catimbau pelos ramos pilosos a velutinos, folhas 3-folioladas com folíolos obovais a suborbiculares, face adaxial vilosa, ápice arredondado, às vezes agudo e mucronado, cálice com 5 dentes, viloso e fruto viloso com margem arqueada. Floração nas duas estações e frutificação na estação chuvosa.

Material selecionado: Buíque, Chapadão, 30.V.2012, fr., G.C. Delgado-Junior et al. 322 (UFP); Fazenda Brejo São José, 15.I.2013, fl., G.C. Delgado-Junior et al. 590 (UFP).

68. Macroptilium bracteatum (Nees \& Mart.) Maréchal \& Baudet, Bull. Jard. Bot. Belg. 44(3-4): 443. 1974.

Fig 3g,n

Caracterizada no PARNA Catimbau pelos ramos pilosos a vilosos, folhas 3-folioladas com folíolos deltoides, lanceolados ou assimétricos, pilosos a glabros, fascículo de brácteas na base do pedúnculo, dentes do cálice menores que o tubo e 
frutos lineares com comprimento superior a $>5 \mathrm{~cm}$. Floração e frutificação na estação seca.

Material examinado: Buíque, Estrada para o Alcobaça, 31.VIII.2013, fl. e fr., G.C. Delgado-Junior et al. 694 (UFP).

69. Macroptilium martii (Benth.) Maréchal \& Baudet, Bull. Jard. Bot. Natl. Belg. 47(1/2): 257. 1977.

Fig. 3i,j

É reconhecida no PARNA Catimbau pelos ramos vilosos a lanosos, folhas 3-folioladas com folíolos suborbiculares a ovais ou assimétricos, vilosos, cálice densamente lanoso com os dentes maiores que o tubo, alas vermelhas e frutos falcados com comprimento igual ou inferior a $3 \mathrm{~cm}$. Floração e frutificação na estação chuvosa.

Material selecionado: Buíque, Serrinha, 3.VII.2013, fl. e fr., G.C. Delgado-Junior et al. 670 (UFP).

70. Periandra coccinea (Schrad.) Benth., Comm. Legum. Gen. 58. 1837.

Fig. 3k

Difere-se das demais trepadeiras do PARNA

Catimbau pelos ramos pubescentes, folhas

3 -folioladas, folíolos com largura igual ou inferior a 2,5 cm, obovais a elípticos, glabrescentes a vilosos, inflorescência com até 5 flores, corola vermelha e cálice campanulado. Floração e frutificação na seca. Material selecionado: Buíque, Fazenda Brejo de São José, 16.I.2013, fl. e fr., G.C. Delgado-Junior et al. 603 (UFP).

71. Vigna luteola (Jacq.) Benth., in Mart. Fl. bras. 15(1): 194. 1859.

Espécie reconhecida no PARNA Catimbau pelos ramos esparsamente hirsutos, base da estípula auriculada, folhas 3-folioladas com folíolos lanceolados, pubescentes, brácteas com largura inferior a $1,5 \mathrm{~mm}$, corola amarela e flores congestas no ápice da inflorescência. Floração na estação seca e frutificação não observada.

Material examinado: Buíque, Fazenda São José, 15.I.2013, fl., G.C. Delgado-Junior et al. 591 (UFP).

Loganiaceae R. Br. ex Mart.

72. Strychnos gardneri DC., Prodr. 9: 14. 1845.

Fig. $2 \mathrm{i}$

É reconhecida no PARNA Catimbau pelas gavinhas em forma de ganchos e pelas folhas com venação trinérvea, coriáceas, elípticas, face adaxial glabra e face abaxial com tricomas restritos a axila do par interno da nervuras principais. Floração na estação seca e frutificação não observada.

Material examinado: Buíque, Casa de Farinha, 9.VIII.2012, bt., fl., G.C. Delgado Junior et al. 413 (UFP).
73. Strychnos rubiginosa DC. Prodr. 9: 16. 1845.

Difere-se das demais trepadeiras do PARNA Catimbau pelas gavinhas em forma de ganchos, folhas com venação trinérvea, elípticas a ovais, pubescentes e pelo cálice pubescente com tricomas ferrugíneos. Floração nas duas estações e frutificação não observada.

Material examinado: Buíque, Estrada para o Juá, 8.V.2013, bt., G.C. Delgado-Junior et al. 665 (UFP). Pedra da cocha, 8.X.2012, fl. G.C. Delgado-Junior et al. 470 (UFP).

Malpighiaceae Juss.

74. Banisteriopsis muricata (Cav.) Cuatrec., Webbia 13(2): 503-504. 1958.

É reconhecida no PARNA Catimbau pelos ramos pubescentes, folhas elípticas a ovais, face abaxial canescente, base cuneada, pecíolo com glândulas, inflorescência em cimeira de umbela e cálice com elaióforos. Floração e frutificação nas duas estações.

Material selecionado: Buíque, Trilha para Cachoeira, 12.IX.2012, fl., G.C. Delgado-Junior et al. 431 (UFP); Sítio Barro Branco, 1.VI.2012, fr., G.C. Delgado-Junior et al. 365 (UFP).

75. Banisteriopsis stellaris (Griseb.) B. Gates, Fl. Neotrop. Monogr. 30: 71, f. 13. 1982.

É reconhecida no PARNA Catimbau pelos ramos glabros, folhas elípticas a ovais, face adaxial glabrescente a glabra, às vezes com tricomas na margem, base subcordada, glândulas nas nervuras da face abaxial e inflorescência em umbela com 4 flores. Floração e frutificação nas duas estações. Material selecionado: Buíque, Serra de Jerusalém, 9.VIII.2012, fl., G.C. Delgado-Junior et al. 415 (UFP); Serrinha, 3.VII.2013, bt., fl. e fr., G.C. Delgado-Junior et al. 671 (UFP).

76. Carolus chasei (W.R. Anderson) W.R. Anderson, Novon 16(2): 187. 2006.

Distingue-se das demais trepadeiras do PARNA Catimbau pelos ramos glabrescentes a glabros, folhas elípticas com face adaxial glabrescente a glabra, abaxial velutina, pedicelo com comprimento inferior a $6 \mathrm{~mm}$, cálice com elaióforo e corola densamente serícea. Frutificação na seca e floração não observada.

Material selecionado: Buíque, Igrejinha, 2.IX.2004, fr., A. Rocha 1229 (IPA).

77. Diplopterys lutea (Griseb.) W.R. Anderson \& C. Davis, Harvard Pap. Bot. 11(1): 10. 2006.

Pode ser reconhecida no PARNA Catimbau pelas folhas ovais, lanosas (jovens), glabrescentes 
a glabras (maduras), pedicelo com comprimento superior a $1 \mathrm{~cm}$, cálice sem elaióforo, pétalas amarelas, fimbriadas na margem. Floração na estação seca e frutificação não observada.

Material selecionado: Buíque, Estrada para o Alcobaça, 10.X.2012, f1., G.C. Delgado Junior et al. 501 (UFP).

78. Diplopterys pubipetala (A. Jussieu) W.R. Anderson \& Davis, Harvard Pap. Bot. 11(1): 13. 2006.

É reconhecida no PARNA Catimbau pelas folhas obovais a ovais, glabras, margem revoluta, pecíolo com comprimento superior a $3 \mathrm{~mm}$, corola amarela e cálice com elaióforos. Floração na estação chuvosa e frutificação na estação seca. Material selecionado: Buíque, Serra de Jerusalém, 7.VII.2012, fr., G.C. Delgado-Junior et al. 373 (UFP). Serra Branca, 8.X.2012, bt., G.C. Delgado-Junior et al. 475 (UFP).

79. Heteropterys byrsonimifolia A. Juss., Arch. Mus. Hist. Nat., 3: 464. 1843.

Difere-se das demais trepadeiras do PARNA Catimbau pelas folhas elípticas, glabras a glabrescentes, base cuneada, indumento ferrugíneo no eixo da inflorescência e pedicelo com comprimento igual ou inferior a $1 \mathrm{~cm}$. Floração na estação seca e frutificação não observada.

Material examinado: Buíque, Quixel, 9.VIII.2012, f1., G.C. Delgado-Junior et al. 422 (UFP).

80. Heteropterys caducibracteata W.R. Anderson, Contr. Univ. Michigan Herb. 15: 118-120, f. 9. 1982.

Espécie reconhecida no PARNA do Catimbau pelos ramos glabros a glabrescentes, folhas ovais a elípticas com face adaxial glabrescente a glabra, face abaxial tomentosa, glândulas ausentes ao longo da margem foliar, corola amarela e cálice com elaióforos. Floração não observada e frutificação na estação chuvosa. Material examinado Buíque, Chapada São José, 2.VII.1975, fr., Andrade-lima (IPA 42962).

81. Heteropterys trichanthera A. Juss., Arch. Mus. Hist. Nat. 3: 438. 1843.

É reconhecida no PARNA Catimbau pelos ramos glabros, folhas ovais a elípticas, face adaxial pilosa, glândulas esparsas ao longo da margem da face abaxial, sépalas com elaióforos e corola amarela. Floração não observada e frutificação na estação chuvosa.
Material examinado: Ibimirim. Ibimirim-Catimbau, 3.VII.1995, fr., A.P.S. Gomes et al. 29 (PEUFR).

82. Janusia anisandra (A.Juss.) Griseb., in Mart. Fl. bras. 12(1): 103. 1858.

Difere-se das demais trepadeiras do PARNA Catimbau pelos ramos glabros, folhas ovais, face adaxial glabrescente, abaxial lanosa, ápice agudo, base cordada a arredondada, inflorescência em panícula, pedúnculo maior que o pedicelo, corola amarela, sépalas com elaióforos e fruto sâmara. Floração nas duas estações e frutificação na seca. Material selecionado: Buíque, Cachoeira, 12.IX.2012, bt., fl. e fr., G.C. Delgado-Junior et al. 433 (UFP).

83. Mascagnia sepium (A. Juss.) Griseb., in Mart. Fl. bras. 12(1): 96. 1858.

É reconhecida no PARNA Catimbau pelas folhas ovais, face adaxial glabrescente a glabra, abaxial pilosa com tricomas ferrugíneos, base arredondada ou cordada, corola amarela e fruto sâmara com alas laterais membranáceas com nervuras reticuladas. Floração na seca e frutificação não observada.

Material selecionado: Buíque, Alcobaça, 31.VIII.2013, bt., fl., G.C. Delgado-Junior et al. 698 (UFP, HUEFS).

84. Stigmaphyllon auriculatum (Cav.) A. Juss., In St.-Hilaire Fl. bras. mer. 3: 48. 1833 [“1832”].

Fig. $2 \mathrm{j}, \mathrm{k}$

Diferencia-se das demais trepadeiras do PARNA Catimbau pelos ramos pubescentes, folhas membranáceas, elípticas, ovais ou triangulares, glabras, glândulas filiformes espalhadas ao longo da margem e pecíolo com um par de glândulas no ápice. Floração e frutificação nas duas estações.

Material selecionado: Buíque, Estrada para o Alcobaça, 9.V.2013, fl. e fr., G.C. Delgado-Junior et al. 658 (UFP).

Passifloraceae Juss. ex Roussel

85. Passiflora cincinnata Mast., Gard. Chron., 1868: 966. 1868.

É reconhecida no PARNA Catimbau pelos ramos glabros, folhas simples 5-partidas, lobos elípticos a oblongos, glabrescentes a glabras, par de glândulas no pecíolo e corola violáceas. Floração nas duas estações e frutificação não observada.

Material selecionado: Buíque, Serra de Jerusalém, 7.VII.2012, fl., G.C. Delgado-Junior et al. 387 (UFP).

\section{Passiflora foetida L., Sp. Pl. 2: 959.}

É reconhecida no PARNA Catimbau pelos tricomas glandulares nos ramos, folhas, brácteas e estípulas; folhas ovais, vilosas e pelas estípulas 
pinatissectas. Floração nas duas estações e frutificação na estação chuvosa.

Material selecionado: Buíque, Chapadão, 30.V.2012, f1., G.C. Delgado Junior et al. 323 (UFP); Sítio Barro Branco, 1.VII.2012. fl. e fr., G.C. Delgado-Junior et al. 355 (UFP).

87. Passiflora luetzelburgii Harms, Repert. Spec. Nov. Regni Veg. 19: 32. 1923.

Difere-se das demais trepadeiras do PARNA Catimbau pelos ramos pubescentes a velutinos, folhas com comprimento superior a $4 \mathrm{~cm}$, ovais, velutinas, ápice agudo a arredondado, base cuneada, glândulas na região mediano-basal do pecíolo, flores solitárias, corola vermelha e fruto baga. Floração nas duas estações e a frutificação na estação chuvosa.

Material selecionado: Buíque, Estrada para o Sítio Juá, 17.I.2013, fl., G.C. Delgado-Junior et al. 610 (UFP); Serra Branca, 31.V.2012, fl. e fr., G.C. Delgado-Junior et al. 330 (UFP).

88. Passiflora silvestris Vell., Fl. Flumin. 9: t. 74.

Diferencia-se das demais espécies do PARNA Catimbau por ser inteiramente glabra, com estípula superior a $1 \mathrm{~cm}$ de comprimento, oval-lanceolada, folhas oblongo-lanceoladas, glândulas no pecíolo e corola branca. Floração na estação chuvosa e frutificação não observada. Material examinado: Buíque, Vale do Catimbau, 27.II.2002, fl., I.C. Lopes et al. (UFP 31789).

Polygalaceae Hoffmanns. \& Link 89. Securidaca diversifolia (L.) S.F. Blake, Contr. U.S. Natl. Herb. 23(3): $594 . \quad$ Fig. 3q

É reconhecida no PARNA Catimbau pelas folhas elípticas a lanceoladas, pubescentes a glabrescentes, glândulas extraflorais na inserção do pecíolo no ramo e no pedicelo, inflorescência em racemo, corola lilás, fruto sâmara 1-alada. Floração nas duas estações e a frutificação na estação seca. Material selecionado: Buíque, Quixel, 9.X.2012, fl. e fr., G.C.Delgado Junior et al. 492 (UFP).

Rhamnaceae Juss.

90. Gouania colurnifolia Reissek, in Mart. Fl. bras. 11(1): 107, t. 26, f. 9.1861.

É reconhecida no PARNA Catimbau pelas gavinhas nos ramos e/ou nas inflorescências, folhas ovais, pubescentes a velutinas, margem serreada na metade distal e com glândulas na margem da face abaxial, corola creme e esquizocarpo 3-alado, velutino. Floração e frutificação na estação chuvosa.
Material examinado: Buíque, Serra do Catimbau, 19.IV.1994, fr., A. Miranda et al. 1795 (PEUFR).

Sapindaceae Juss.

91. Cardiospermum corindum L., Sp. Pl. (ed. 2) 1: 526.

Fig. 2c

Diferencia-se das demais trepadeiras do PARNA Catimbau pelas folhas 5-folioladas com folíolos ovais, pilosos, ápice acuminado, base cuneada, inflorescência com até 4-6 ramos secundários reunidos no ápice da raque e pelas cápsulas infladas. Floração e frutificação nas duas estações.

Material selecionado: Buíque, Chapadão, 13.IX.2012, fr., G.C. Delgado-Junior et al. 462 (UFP); Fazenda laranjeira, 19.V.2005, fl. e fr., Inácio 59 (PEUFR).

92. Serjania glabrata Kunth. Nov. Gen. Sp. (quarto ed.) 5: 110. 1821.

Fig. 2d

Pode ser reconhecida no PARNA Catimbau pelos ramos pubescentes a velutinos, gavinhas na inflorescência e ao longo do ramo, folhas 5-folioladas com folíolos ovais a romboide, face abaxial velutina com indumento esbranquiçado, ápice agudo e base cuneada. Floração e frutificação nas duas estações. Material selecionado: Buíque, Brocotó, 8.VIII.2012, fl., G.C. Delgado-Junior et al. 399 (UFP); Chapadão, 30.V.2012, fr, G.C. Delgado-Junior et al. 324 (UFP).

93. Serjania lethalis A. St.-Hil., Hist. Pl. Remarq. Bresil, 1: 206. 1824.

Difere-se das demais trepadeiras do PARNA Catimbau pelos ramos pubescentes a glabrescentes, gavinhas na inflorescência, folhas 5-folioladas com folíolos ovais a elípticos, glabros, ápice agudo e base cuneada. Floração e frutificação na estação seca.

Material selecionado: Buíque, Trilha do camelo, 5.XII.2012, fr., G.C. Delgado-Junior et al. 556 (UFP); Estrada para a Vila do Catimbau, 8.X.2012, fr. G.C. Delgado-Junior et al. 465 (UFP).

94. Serjania marginata Casar., Nov. Stirp. Bras. 5: 44. 1843.

Fig. 2b

Difere-se das demais trepadeiras do PARNA Catimbau pelos ramos pubescentes a glabrescentes, gavinhas na inflorescência, folhas 5-folioladas com folíolos com raque alada, ovais, elípticos a obovais, pubescentes a glabrescentes, ápice agudo a arredondando e base cuneada a aguda. Floração nas duas estações e frutificação na estação chuvosa. Material selecionado: Buíque, Cachoeira, 12.IX.2012, bt., fl., G.C. Delgado-Junior et al. 437 (UFP); Fazenda laranjeira, 16.VII.1995, fl. e fr. Figueirêdo et al. 94 (PEUFR). 
95. Serjania pernambucensis Radlk., in Mart. Fl. bras. 13(3): 332. 1892.

É caracterizada no PARNA Catimbau pelos ramos tomentosos, gavinhas na inflorescência, folhas 5-folioladas com folíolos lanceolados a oblongos ou ovais, face abaxial pubescente com indumento ferrugíneo, ápice agudo e base cuneada. Floração na estação chuvosa e frutificação não observada.

Material selecionado: Buíque, Estrada CatimbauBuíque, 11.VII.1997, fl., A. Miranda et al. 2740 (HST).

96. Urvillea ulmacea Kunth, Nov. Gen. Sp. (quarto ed.) 5: 106, pl. 440. 1821.

Reconhecida no PARNA Catimbau pelos ramos pilosos, folhas 3-folioladas com folíolos ovais, pilosos, ápice acuminado, base cuneada e cápsula inflada na região central, alada. Floração na estação chuvosa e frutificação não observada.

Material examinado: Buíque, Estrada BuíqueCatimbau, 11.VII.1997, bt. e fl., A.C. Lacerda et al. (HST 6802).

\section{Smilacaceae Vent.}

97. Smilax campestris Griseb., in Mart. Fl. bras. 3(1): 15.1842.

É reconhecida no PARNA Catimbau por apresentar um par de gavinhas na base do pecíolo, folhas coriáceas, ovais, elípticas, oblongas a cordadas, glabras, com 3-5 nervuras proeminentes na face abaxial e inflorescência em umbela. Floração e frutificação na seca.

Material selecionado: Buíque, Trilha do Camelo, 5.XII.2012, fl., G.C. Delgado-Junior et al. 557 (UFP); Serra de Jerusálem, 12.IX.2012, fr., G.C. Delgado-Junior et al. 499 (UFP).

98. Smilax cissoides Mart. ex Griseb., in Mart. Fl. bras. 3(1): 8.1842.

Difere-se das demais trepadeiras do PARNA Catimbau por apresentar um par de gavinhas na base do pecíolo, folhas membranáceas a cartáceas, ovais, glabras, com 7 ou mais nervuras primárias proeminentes na face abaxial e inflorescência em umbela. Floração e frutificação na seca.

Material selecionado: Buíque, Quixel, 12.IX.2012, bt., G.C. Delgado-Junior et al. 456 (UFP).

Trigoniaceae A. Juss.

99. Trigonia nivea Cambess., Fl. Bras. Merid. (quarto ed.) 2(13): 113. 1829.

É reconhecida no PARNA Catimbau pelos ramos lanosos a glabros, folhas oblongo-elípticas, oblanceoladas a oblongas, face abaxial lanosa com tricomas esbranquiçados, ápice agudo a obtuso, raro mucronado, base cuneada, nervuras secundárias proeminentes, corola alva, pedicelo com comprimento superior a $2 \mathrm{~mm}$ e fruto cápsula septicida. Floração e frutificação na estação seca. Material selecionado: Buíque, Quixel, 9.VIII.2012, fl. e fr., G.C. Delgado-Junior et al. 423 (UFP).

Vitaceae Juss.

100. Cissus blanchetiana Planch., Monogr. Phan. 5: 556. 1887.

É reconhecida no PARNA Catimbau pelos ramos velutinos a glabrescentes, gavinhas opostas às folhas e pelos folíolos ovais, oblongos a elípticos, face abaxial tomentosa com indumento ferrugíneo, ápice agudo a acuminado, base arredondada a subcordada, inflorescência umbeliforme e fruto baga. Floração não observada e frutificação na estação chuvosa.

Material examinado: Buíque, Serra de Jerusalém, 30.V.2012, fr., G.C. Delgado-Junior et al. 317 (UFP).

101. Cissus verticillata $(\mathrm{L}$.$) Nicolson \& C.E. Jarvis,$ Taxon 33(4): 727. 1984.

Distingue-se das demais trepadeiras do PARNA Catimbau pelas gavinhas opostas às folhas; folhas ovais, tricomas restritos às nervuras na face abaxial, ápice agudo a cuspidado, base subcordada a emarginada, pecíolo glabro, inflorescência em panícula de umbela, corola creme-esverdeada e fruto baga. Floração e frutificação na estação chuvosa. Material examinado: Búque, Sítio Palmeirinha, 19.VII.2008, fl. e fr., R. Pereira et al. 2700 (IPA).

\section{Agradecimentos}

Agradecemos o apoio financeiro concedido pela CAPES e pelo CNPq. Aos especialistas que auxiliaram nas identificações: Géssica Costa (Cucurbitaceae); Teresa Buril (Convolvulaceae); Diogo Araújo (Dioscoreaceae); André Amorim e Rafael Almeida (Malpighiaceae); e Luiz Aquino (Sapindaceae). Aos curadores e funcionários dos Herbários ASE, HST, HVASF, IPA, JPA PEUFR e UFP. A Anderson Feijó, a confecção do mapa. E a Regina Carvalho, as Ilustrações.

\section{Referências}

Acevedo-Rodríguez, P. 2003. Bejucos y plantas trepadoras de Puerto Rico e Islas Virgenes. Smithsonian Institution, Washington. 491p.

Araújo, D. \& Alves, M. 2010. Climbing plants of fragmented area of lowland Atlantic Forest, Igarassu, Pernambuco (Northeastern Brazil). Phytotaxa 8: 1-24. 
Araújo, D. 2014. Trepadeiras do bioma Caatinga. In: Villagra, B.L.P.; Melo, M.M.R.F.; Romaniuc-Neto, S. \& Barbosa, L.M. Diversidade e conservação de trepadeiras: contribuições para a restauração de ecossistemas brasileiros. Imprensa Oficial do Estado de São Paulo, São Paulo. Pp. 35-57.

APGIV. 2016. An update of the Angiosperm Phylogeny group classification for the orders and families of families flowering plants: APGIV. Botanical Journal of the Linnean Society 181: 1-20.

Barros, A.A.M.; Ribas, L.A. \& Araujo, D.S.D. 2009. Trepadeiras do Parque Estadual da Serra da Tiririca, Rio de Janeiro, Brasil. Rodriguésia 60: 681-694.

BGF. 2015. Growing knowledge: an overview of seed plant diversity in Brazil. Rodriguésia 66: 2-29.

Buril, M.T. \& Alves, M. 2011. A new species of Jacquemontia (Convolvulaceae) from Northeastern Brazil. Brittonia 63: 436-441.

Carneiro, J.S. \& Vieira, A.O. 2012. Trepadeiras: florística da Estação Ecológica do Caiuá e chave de identificação vegetativa para espécies do Norte do estado do Paraná. Acta Scientiarum 34: 217-224.

CPRM. 2001. Geologia e recursos minerais do estado de Pernambuco. Serviço geológico do Brasil. Disponível em <http://rigeo.cprm.gov.br/xmlui/ bitstream/handle/doc/2422/Geologia_Rec_Min PE.pdf? sequence=1>. Acesso em 26 abril 2016.

Cruz, J.A.; Araújo, E.L.; Ferraz, E.M.N. \& Silva, S.I. 2010. Plantas trepadeiras da Caatinga: aspectos da distribuição e usos baseados no checklist dos herbários de Pernambuco- Brasil. In: Albuquerque, U.P.; Moura, A.N. \& Araújo, E.L. Biodiversidade, potencial econômico e processos eco-fisiológicos em ecossistemas nordestinos. Canal 6, Bauru. Pp. 217-251.

DOU - Diário Oficial da União. 2002. Decreto 913/12 de 13 de dezembro de 2002. N. 242. 16 de dezembro de 2002. Brasília. Pp. 13-14.

Durigon, J.; Canto-Dorow, T.S. \& Eisinger, S.M. 2009. Composição florística de trepadeiras ocorrentes em bordas de fragmentos de floresta estacional, Santa Maria, Rio Grande do Sul, Brasil. Rodriguésia 60: 415-422.

Durigon, J. \& Waechter, J.L. 2011. Floristic composition and biogeographic relations of a subtropical assemblage of climbing plants. Biodiversty and Conservation 20: 1027-1044.

Fiaschi, P. \& Pirani, J.R. 2009. Review of plant biogeografic studies in Brazil. Journal of Systematics and Evolution 47: 477-496.

García-Gonzalez, J.D. 2011. Diversidade e abundância de lianas em uma área de Floresta Atlântica Semidecidual ao norte do estado de Pernambuco. Dissertação. Universidade Federal de Pernambuco, Recife. 103 p.

Gentry, A.G. 1991. The distribution and evolution of climbing plants. In: Putz, F.E. \& Mooney \& H.A. The biology of vines. Great Britain at University Press, Cambridge. Pp 3-52.
Harris, J.G. \& Harris M.W. 2000. Plant identification terminology: an illustrated glossary. Spring Lake Publishing, Spring Lake. 197p.

Hora, R.C. 2004. Composição, distribuição e organização espacial das lianas em uma floresta estacional semidecidual em São Carlos - SP. Tese em Ecologia e Recursos Naturais. Universidade Federal de São Carlos, São Paulo. 74p.

IBGE. 2013. Histórico: Buíque Pernambuco - PE. Disponível em <http://cidades.ibge.gov.br/painel/ historico.php? codmun $=260280>$. Acesso em 10 dezembro 2013.

Mori, S.A.; Mattos-Silva, L.A.; Lisboa, G. \& Coradin, L. 1985. Manual de manejo do herbário fanerogâmico. CEPLAC/CEPEC, Ilhéus. 104p.

Oliveira, A.C.P.; Mota, L.M. \& Loiola, M.I.B. 2012. Diversidade florística e chave de identificação de trepadeiras em uma floresta estacional semidecidual em Parnamirim - RN, Brasil. Revista Caatinga 25: 153-158.

Pax, F. \& Hoffmann, K. 1919. Euphorbiaceae, Dalechampieae. In: Engler, A. Das Panzenreich. Wllhelm Engelmann, Leipzig. Pp. 1-59.

Putz, F.E. 1984. The natural history of lianas on Barro Colorado Island, Panama. Journal of Ecology 16: 1713-1724.

Queiroz L.P. 2006. The Brazilian Caatinga: phytogeographical patterns inferred from distribution data of the Leguminosae. In: Pennington, R.T.; Lewis, G.P. \& Ratter, J.A. Neotropical savannas and seasonally dry forests: plant diversity, biogeography and conservation. CRC Press, Boca Raton. Pp. 121-157.

Rezende, A.A. \& Ranga, N.T. 2005. Lianas da estação ecológica do noroeste paulista, São José do Rio Preto/Mirassol, SP, Brasil. Acta Botanica Brasilica 19: 273-379.

Rodal, M.J.L.; Andrade, K.V.S.; Sales, M.F. \& Gomes, A.P.S. 1998. Fitossociologia do componente lenhoso de um refúgio vegetacional no município de Buíque, Pernambuco. Revista Brasileira de Biologia 58: 517-526.

SADMET/INMET. Seção de armazenamento de dados meteorológicos/Instituto de meteorologia. 2013. Disponível em <http://www.inmet.gov.br/html/ central_servicos/combo_produtos.html >. Acesso em 24 maio 2013.

Sampaio, P.S.P. 2004. Levantamento florístico das lianas de uma restinga na praia do Itaguaré, município de Bertioga, São Paulo, Brasil. Dissertação em Botânica. Universidade de São Paulo, São Paulo. 176p.

Sampaio, E.V.S.B.; Giulietti, A.M.; Virgínio, J. \& Gamarra-Rojas, C. 2002. Vegetação e Flora da Caatinga. Associação de plantas do Nordeste (APNE) e Centro Nordestino de Informações sobre Plantas (CNIP), Recife. Pp. 49-90.

Santos, K.; Kinoshita, L.S; \& Rezende, A.A. 2009. Species composition of climbers in seasonal semideciduous 
forest fragments of Southeastern Brazil. Revista Biota Neotropica 9: 175-188.

Schnitzer, S.A. \& Bongers, F. 2002. The ecology of lianas and their role in forests. Trends Ecol Evol 17: 223-230.

Souza-Silva, R.F. de; Rapini, A. \& Morales, J.F. 2010. Mandevilla catimbauensis (Apocynaceae), a new species from the semiarid region, Pernambuco, Brazil. Edinburgh Journal of Botany 67: 1-5.

Stearn, W.T. 2004. Botanical Latin. David \& Charles Publishers, Newton Abbot. 546p.

Tibiriçá, Y.J.A.; Coellho, L.F.M \& Moura, L.C. 2006. Florística de lianas em um fragmento de floresta estacional semidecidual, Parque Estadual de Vassununga, Santa Rita do Passa Quatro, SP, Brasil. Acta Botanica Brasilica 20: 339-346

Udulutsch, R.G.; Assis, M.A \& Picchi, D.G. 2004. Florística de trepadeiras numa floresta estacional semidecídua, Rio Claro/Araras, estado de São Paulo, Brasil. Revista de Botânica 27: 125-134.

Udulutsch, R.G.; Souza, V.C.; Rodrigues, R.R \& Dias, P. 2010. Composição florística e chaves de identificação para lianas da Estação Ecológica dos
Caetetus, estado de São Paulo, Brasil. Rodriguésia 61: 715-730

Vargas, B.C.; Araújo, G.M.; Schiavini, I.; Rosa, P.O. \& Hattori, E.K.O. 2013. Florística de trepadeiras em floresta semidecidual e em mata ciliar no vale do rio Araguari, MG. Bioscience Journal 29: 185-197.

Vargas, B.C. \& Araújo, G.M. 2014. Florística de trepadeiras em fragmentos de florestas semideciduais em Uberlândia, Minas Gerais, Brasil. Rodriguésia 45: 49-59.

Villagra, B.L.P. \& Romaniuc-Neto, S. 2010. Florística de trepadeiras no Parque Estadual das Fontes do Ipiranga, São Paulo, SP, Brasil. Revista Brasileira de Biociências 8: 186-200.

Villagra, B.L.P. 2012. Estrutura da comunidade de trepadeiras em Mata Atlântica, Santo André, SP, Brasil. Tese de Doutorado. Instituto de Botânica da Secretaria de Estado do Meio Ambiente, São Paulo. 150p.

Webster, G.L. \& Armbruster, W.S. 1991. A synopsis of the neotropical species of Dalechampia (Euphorbiaceae). Botanical Journal of the Linnean Society 105: 137-177. 


\section{Lista de exsicatas}

Alves-Araújo, A. 56 (15). Alcântara, G.D. 12 (21). Andrade, K. 34 (40), 88 (14), 106 (9), 121 (4), 229 (22), 235 (15), 236 (14), 255 (82), 320 (15), 337 (9), 345 (75). Baracho, G.S. 244 (21), 254 (82). Bocage, A. 1051 (15), 1063 (77), 1077 (66), 1080 (70), 1085 (93), 1106 (99). Cano, O. 17 (34), 410 (58), 702 (42), 708 (62), 711 (76), 722 (21), 776 (11), 778 (70), 787 (91), 794 (37), 800 (85), 812 (92). Cantarelli, J. 503 (5). Carvalho, A.T. 2 (16), 4 (21). Costa, A.C.G. 19 (34), 23 (5), 33 (15), 44 (4). Correia, M. 199 (14). Delgado-Junior, G.C. 295 (15), 296 (37), 300 (22), 308 (37), 318 (34), 319 (58), 323 (86), 326 (19), 327 (85), 328 (15), 338 (75), 339 (58), 347 (32), 348 (85), 350 (15), 351 (13), 353 (74), 354 (66), 355 (86), 356 (74), 357 (91), 358 (34), 359 (32), 360 (87), 361 (67), 363 (84), 368 (32), 375 (74), 381 (54), 383 (4), 385 (9), 390 (64), 393 (8), 395 (64), 398 (94), 405 (93), 406 (39), 408 (54), $410(58)$, 412 (47), 418 (39), 421 (16), 427 (53), 430 (39), 440 (41), 443 (87), 444 (7), 450 (82), 454 (9), 455 (9), 457 (38), 458 (4), 459 (93), 462 (91), 466 (15), 478 (82), 482 (98), 485 (7), 488 (8), 491 (70), 559 (11), 581 (93), 583 (63), 587 (13), 588 (99), 589 (92), 590 (67), 596 (63), 599 (89), 604 (59), 605 (9), 606 (67), 608 (15), $616(20), 618$ (5), $619(34), 621(19), 622(84), 625(67), 626(54), 627(8), 629$ (8), 631 (76), 634 (8), 637 (99), 638 (20), 642 (26), 643 (16), 644 (16), 646 (17), 649 (20), 650 (16), 652 (16), 655 (16), 658 (84), 659 (17), 660 (16), 666 (8), 674 (47), 675 (47), 687 (21), 699 (54), 701 (48), 708 (85), 689 (69), 709 (74), 710 (62), 711 (56), 714 (22), 717 (20), 721 (33). Figueirêdo, L.S. 35 (14), 64 (75), 71 (9), 77 (14), 104 (9), 108 (32), 109 (26), 111 (30), 135 (82), 229 (15), 233248 (70), (18), 266 (15), 284 (4). Frazão, A.A. HST 6807 (25), HST 10106 (14). Freire, E. 22 (9), 34 (14), 101 (9). Gomes, A.P.S. 19 (15), 278 (16), 328 (13), 336A (9), 379 (18). Gomes, P. 68 (34), 69 (37), 70 (37), 81 (7), 194 (5). Hora, M.J. 41 (15), 53 (15). Lacerda, A.C. HST 7195 (25), HST 10114 (24). Laurênio, A. 15 (4), 24 (21), 27 (15), 63 (19), 322 (4), 423 (19), 2055 (58). Lemos. J.R. 84 (26). Martins, S. 180 (13). Miranda, A.M. 576 (8), 1715 (9), 1751 (14), 1754 (4), 1756 (87), 1758 (58), 1763 (9), 1778 (7), 1782 (14), 1828 (37), 1833 (78), 2272 (15), 2280 (15), 2485 (44), 2688 (25), 2811 (78), 2825 (21), 4480 (21), 4487 (22), 5661 (21), 5662 (17), 5710 (30). Nadia, T. de L. 221 (9), 222 (9), 224 (9), 223 (14). Oliveira, C.R.S. 60 (4), 190 (13), 205 (9), 234 (37), 315 (26), 352 (86), 384 (5). Oliveira, H.B. 13 (19), 16 (66). Oliveira, M. 140 (93), 2202 (29), 5431 (14), 5455 (13). Pereira, R. 1021 (9), 2702 (91), 2706 (29), 2710 (92), 2724 (31), 2725 (30), 2729 (26), 2730 (23), 2777 (31), 2843 (11), 2874 (74). Pick, R.A. 64 (38), 75 (15), 94 (21), 173 (66), 212 (37), 241 (25), 261 (74), 263 (37), 270 (38), 279 (33), 314 (38), 317 (41). Pinho, R.S. 03 (15). Rocha, E.A. 1182 (85), 1224 (91), 1262 (65), 1480 (94), 1484 (75), 1491 (11), 1501 (22), 1529 (83), 1545 (95), 1555 (21), 1563 (9), $1568(44), 1578$ (74), 1583 (82). Rodal, M.J.N. 291 (7), 430 (14), 447 (75), 519 (55), 529 (14), 532 (30), 533 (26), 543 (9), 544 (9). Rodrigues, A. 18 (32), 20 (37), 21 (4), 22 (7), 57 (37). Sales, M.F. 354 (9), 509 (14), 516 (9), 518 (15). Schlindwein, C. 507 (86), 1218 (15), 1255 (67). Silva, A.G. 1664 (32). Siqueira-Filho, J.A. 271 (89), 2905 (13), 2924 (74). Souza, E.R. de 393a (4), 396 (24). Villarouco, F.M.O. 03 (9). Vital, M.T. 17 (34), 20 (37), 22 (37), 23 (45), 38 (42), 39 (44), 40 (25), 42 (33), 43 (25), 44 (44), 45 (38). 